\title{
Removal of Chromium and Azo Metal-Complex Dyes Using Activated Carbon synthesized from Tannery Wastes
}

\author{
Fasika Kebede ${ }^{1}$ and Alemayehu Gashaw ${ }^{2}$ \\ ${ }^{I}$ Department of Chemistry, Faculty of Natural and Computational Sciences, Bahir Dar University, \\ Bahir Dar, Ethiopia \\ ${ }^{2}$ Department of Chemistry, Faculty of Natural and Computational Sciences, Bule Hora University, \\ Bule Hora, Ethiopia
}

Corresponding Author

Alemayehu Gashaw

alexgashaw@gmail.com

\section{Editor}

Jose M. Guisan

\section{Dates}

Received 7 April 2016

Accepted 29 April 2016

Copyright (C) 2017 Fasika Kebede and Alemayehu Gashaw. This is an open access article distributed under the Creative Commons Attribution License, which permits unrestricted use, distribution, and reproduction in any medium, provided the original work is properly cited.

\begin{abstract}
Leather industries are one of pollution-intensive industrial complexes generating huge volumes of liquid and high concentration of solid wastes. Tanneries use different harmful chemicals like (chromium, sulphuric acid, dyes, etc) in their processing. They could have a number of adverse impacts on the environmental eco-system as well as on the society living around. In this study, fleshed parts of tannery solid wastes were brought from Bahir Dar leather factory to synthesize an activated carbon used for effective removal of chromium, mordant black-11 and red azo dyes from the aqueous solution. Fleshed tannery waste activated carbon (FTWAC) characterized by FTIR which shows acidic properties, surface area by BET was $535.02 \mathrm{~m}^{2} / \mathrm{g}$ and different physical and chemical properties were determined. The concentration of $\mathrm{Cr}(\mathrm{VI})$ was determined by ICP-OES, but mordant black-11 and red azo dyes were determined by UV-Vis spectroscopy instrument. Freundlich isotherm model is well fitted than Langmuir model for the adsorption. Generally the results showed that the removal efficiency of FTWAC for Cr(VI) over 99\%, for mordant black-11 dye over $97 \%$ and red azo dye over $93 \%$ were achieved. Therefore, using FTWAC for treatments of chromium and dyes in the effluent wastes for leather industry is economical and viable option.
\end{abstract}

Keywords: FTWAC; removal efficiency; adsorption capacity; $\mathrm{Cr}(\mathrm{VI})$ mordant black-11; red azo dye

\section{Introduction}

The major causes of water pollution due to toxic heavy metals and dyes are the big concern for chemical and environmental engineers, which is because of excessive release of pollutants into the surrounding environment, due to the expansion of industrialization and urbanization. Metals and dyes are not degradable and easily susceptible to form complex, the formation of complex can results in very slow degradation (Geetha and Belagali, 2013) [12].

The majority of industries such as paper and pulp, cosmetics, paints and pigments, plastics, leather tanning, and textile industries generate a huge amount of colored effluent and considerable amount of toxic metals and the waste effluents need treatment. The discharge of such effluents causes toxicological and aesthetical problems. Out of a number of industries leather tanning industry is a major source of colored effluent and toxic metal discharge to water bodies (Linhares et al., 2013) [17]. Recently surveys found that fast growth of leather production from 
the industrialized countries to the developing countries which occurred between the 1960s and 1980 (known as "The Big Shift") in effect moved the most highly polluting part of the process away from the countries. The tanning industry is known to be very polluting waste disposal mainly through effluents with high in organic and inorganic dissolved and suspended solids content consisted by propensities for high oxygen demand and containing potentially toxic metal salt residues. Unwanted odour generated from the decomposition of protein solid wastes, presence of ammonia, hydrogen sulphide, and volatile organic compounds are normally associated with tanning activities. Some of the chemical used in leather processing is not fully absorbed in the process rather some parts are discharged in to the water body and environment. The liquids effluent from leather processing contains, chromium, sulphide organic matter and solid waste includes fleshing parts, trimmings, wet blue splits, and shavings, buffing dust etc (Yener et al., 2006) [26].

Worldwide production of organic dyes is currently estimated at nearly 450,000 tons, with 50,000 tons being lost in effluents during application and manufacture (Abd-Alredha et al., 2012) [1]. One ton of hide leads to generates of $20-30 \mathrm{~m}^{3}$ of foul smelling wastewater, which includes chromium (100-400 mg/l), sulphide (200-800 mg/l) and other solid waste materials. The release of these toxic substances into water bodies could pollute water and disturb the ecosystem of the aquatic life inside the water (Pandharipande et al., 2012) [20].

The two common oxidation states of chromium have different chemical, biological and environmental characteristics. Trivalent chromium ( $\mathrm{Cr}(\mathrm{III})$ ) is relatively insoluble and required by microorganisms in small quantities as an essential trace metal nutrient, but hexavalent chromium $(\mathrm{Cr}(\mathrm{VI}))$ is a great concern because of its toxicity even in trace amount. As determined by NTP, IARC, and WHO, chromium (VI) is a human carcinogen at a level of above its WHO standard value (Ozgunay et al., 2007; Hauber and Buljan, 2000). According to the WHO, the tolerance limit for $\mathrm{Cr}(\mathrm{VI})$ for discharge into inland surface water is $0.1 \mathrm{mg} / \mathrm{l}$ and in potable water is $0.05 \mathrm{mg} / \mathrm{l}$. Ethiopian Environmental Protection Authority (EPA) also set a minimal standard to be $0.1 \mathrm{mg} / \mathrm{l}$ for hexavalent chromium containing industrial effluent (Belay, 2010) [6].

The other pollutants in many industries such as dyestuff's, paper, textile, plastics and leather use dyes in order to color their products and also consume substantial amount of water (Elinge et al., 2011) [10]. Among the dyes used such as acidic, basic, neutral, mordant, reactive dyes are the most commonly used in leather industry more often basic dyes are usually applicable because of least cost and easy of accessibility. A dye can generally be described as a colored substance that has an affinity to the substrate to which it is being applied and is used to impart color to materials of which it becomes an integral part. Synthetic dyes and pigments are extensively used in dyeing and printing industry. Over ten thousand tons per year and approximately 10,000 dyes are produced annually worldwide, of which $10 \%$ is lost in the industrial effluents (Sivakumar et al., 2012) [24]. The presence of very small amounts of dyes in water even less than 1ppm for some dyes is highly visible and undesirable (Robinson et al., 2001) [22]. Dyes are not only affect the look of natural water, but also highly toxic (Chu, 2001) [8]. Some dyes are reported to harm mammalian and human being cells by causing kidney cancer and reproductive difficulties (Rodri'gues-Reinoso, 1997; Henderson et al., 1997) [14, 23]. These dyes are also potentially carcinogenic, genotoxic, and causes 
direct/indirect change or damage of DNA in many animal species (Henderson et al., 2004) [15].

According to several researchers the concept of "zero emission" was proposed to be an idea of reducing environmental impact produced by discharged waste products and use to increase the effective recycling system in order to minimize the wasted resources (Yoshiyuki and Yutaka, 2003) [27]. Therefore, there are several treatment techniques to treat the effluents. The main techniques which have been utilized to reduce the heavy metal ions content and dyes of effluents include lime precipitation, ion exchange, membrane processing and electrolytic methods. These methods have been found to be limited. Since they often involve high capital and operational costs and may be associated with the generation of secondary waste, which are the present treatment problems. But adsorption using activated carbon is very cheap, effective compared to other methods. The efforts have been contributed to develop new adsorbents and improving the existing adsorbents to have alternative materials to activated carbon (Geetha and Belagali, 2013) [12]. Various carbonaceous materials, such as coal, coconut shell, lignite, wood and peat are used in the production of commercial activated carbon (Bansode et al., 2003) [5]. Activated carbon is a widely used adsorbent for the treatment of industrial wastewater containing color, heavy metals, and other inorganic and organic pollutants. As commercially available activated carbon is a costly natural material, bio-sorbents and waste materials from industry and agriculture are considered more economical alternative sorbents. Activated carbons (AC) are known as very effective adsorbents due to their highly developed porosity; it has large surface area ranges typically from 500 to $1500 \mathrm{~m}^{2} / \mathrm{g}$ (Bansal and Goyal, 2005) [4]. But the surface area has been found to be in excess of $3,000 \mathrm{~m}^{2} / \mathrm{g}$. Moreover the activated carbon has variable characteristics of surface chemistry, and high degree of surface reactivity (Rodr1'gues-Reinoso, 1997) [23]. These unique characteristics make AC very versatile materials, which have been studied not only as adsorbents, but also as catalysts and catalyst supports used for different purposes such as the removal of pollutants from gaseous or liquid phases and the purification or recovery of chemicals.

Presently, utility of activated carbon as an adsorbent is a viable option for removing toxic metal and dyes, and are seen to be taking root in many parts of the country. Ethiopia is home to the largest population of cattle in Africa. In recent years country's leather industry has attracted several foreign companies that have set up factories here and as one of government's priority sectors for investors. A case in point is Bahir Dar leather factory is a privately owned company established in 1998. It gains its inputs (hide and skin) from the surrounding community, the municipal slaughterhouse of the town and from wholesale merchants who collect hide and skin from the local people. In the earlier periods of its establishment the tannery was known for semi-processed products like pickled sheepskins and chromed goat skins. These products were exported to Italy, England, and Indonesia. Currently, the tannery is producing crust and finished and semi-finished leathers like garment, glove leather, and upper shoe leather, leather bags which are exported to Germany, Holland, China, Indonesia and India. However, the factory is generally pollution-intensive industrial complexes generating large volumes and high concentration of liquid and solid wastes. These wastes have historically been discharged in to the rivers (Abay) and land fill waste sites and adverse effects on the workers and the community nearby. Bahir Dar leather factory has a large number of goat and sheep skins used for factory (nearly 150,000) per year. A substantial portion of these skins passes several chemical 

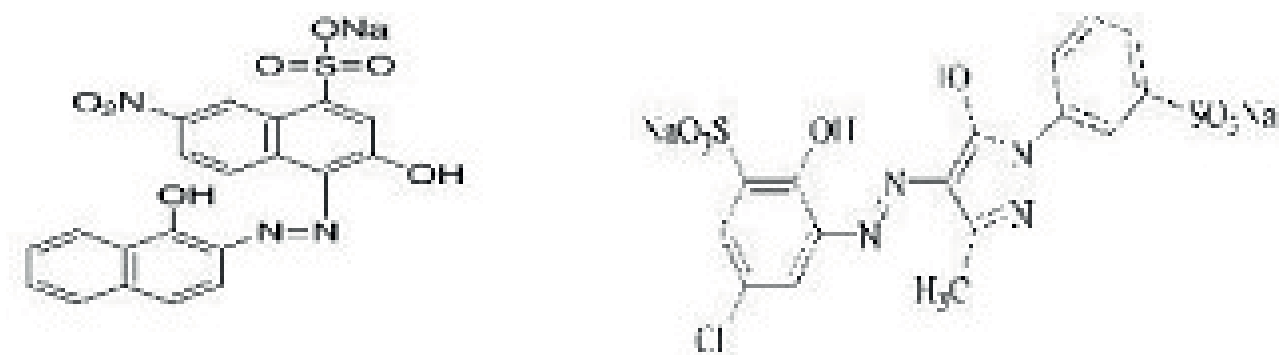

Figure 1: Structure of Mordant black 11 dyes (C.I 15707) (1:2 Chrome) [12392-64-2]. \& red 183 dyes (C.I18800(1:1Chrome)[6408-31-7] (Waring and Hallas, 1990) [25].

treatment processes until to final stage and huge quantities of solid wastes were obtained at each operational stapes. As a result, we have huge quantities of remained parts of solid wastes including flashed parts, ears, legs, hairs, and so on, all of which may be used as substrates for removal and adsorption of toxic metals and dyes using activated carbon synthesized from the solid wastes. In light of this, Bahir Dar leather factory is an unquestionable benefit and attractive recycling wastes to useful and creation of friendly waste disposal to the environmental must be used as one of a viable option.

Mordant Black-11 (C20H12N3NaO7S) dye and red Azodyes (C15H11N4Na2O8S2) of most frequently used dyes according to the customer. Mordant dyes sometimes they call it dyes combined with metal salts (mordanting) to form insoluble colored complexes. These materials are usually used for the dyeing of cotton, wool and protein fiber. The fiber is first treated with aluminum, chromium and iron salt and then contacted with lake forming dye. The metallic precipitate is formed in the fiber producing very fast colors highly resistant to both light and washing. The other dyes used in these work are azo dyes. Azo dyes contain at least one azo group $(-\mathrm{N}=\mathrm{N}-)$ attached to one or more aromatic rings.

\subsection{Statement of the problem}

Most of the Ethiopian leather industry discharges their effluent wastes to the water bodies like rivers. These rivers are the milestone for the large number of the population, since the community around the river used it for drinking, personal hygiene, irrigation etc. Bahir Dar tannery use different harmful chemicals in serious of their processing, they could have a number of adverse effects on the eco-system, residence nearby, as well as the Abay River. Because of the fact that direct disposal of effluents to land and water bodies has the potential to contaminate land surface, air and surface water as well as soils and crops grown on the soils which will have direct impact on human health. However, in this factory less emphasis is given for treatment of the waste, and, there is no treatment methods as such developed. Therefore, beside economical gain, minimizing problem associated with the wastes by recycling and converting wastes to valuable product is one of an alternative option. In general, the main objective of this study is to remove chromium and azo metal-complexes dyes using activated carbon synthesized from tannery wastes. Specifically, this research focuses on production of activated carbon from tannery solid wastes, characterizing the activated carbon, measuring the performance of activated carbon for adsorption of chromium and dyes, developing optimization for chromium (+6) and 
mordant black-11 and azo dyes (Removal efficiency and Adsorption capacity) and measuring the effluents total chromium and $\mathrm{Cr}(+6)$ before and after treatment.

\section{Materials and Methods}

\subsection{Chemicals and equipments}

\subsubsection{Chemicals}

All chemicals used in this work were taken analytical grades;

1. potassium dichromate $\left(\mathrm{K}_{2} \mathrm{Cr}_{2} \mathrm{O}_{7}\right)$ used for the optimization of $\mathrm{Cr}^{+6}$ determination (purity $=99.9 \%$ ), Phenol crystal and 4 -amino antipyrene used for complexing agent

2. Potassium hydrogen phthalate $\left(\mathrm{KHC}_{8} \mathrm{H}_{4} \mathrm{O}_{4}\right)$ used for $\mathrm{pH} 4.01$ buffer

3. Potassium dihydrogen phosphate $\left(\mathrm{KH}_{2} \mathrm{PO}_{4}\right)$ and Disodium hydrogen phosphate $\left(\mathrm{Na}_{2} \mathrm{HPO}_{4}\right)$ used for $\mathrm{pH} 6.86$ buffer and

4. Sodium tetra borate $\left(\mathrm{Na}_{2} \mathrm{~B}_{4} \mathrm{O}_{7} \cdot 10 \mathrm{H}_{2} \mathrm{O}\right)$ used for making buffer solution of $\mathrm{pH} 9.18$ obtained from Chemistry Department at Bahir Dar University

5. Mordant Black-11 dye $\left(\mathrm{C}_{20} \mathrm{H}_{12} \mathrm{~N}_{3} \mathrm{NaO}_{7} \mathrm{~S}\right)$ and red Azo dye $\left(\mathrm{C}_{15} \mathrm{H}_{11} \mathrm{~N}_{4} \mathrm{Na}_{2} \mathrm{O}_{8} \mathrm{~S}_{2}\right)$ from IoTEX of Bahir Dar University

6. Sulfuric acid $\left(\mathrm{H}_{2} \mathrm{SO}_{4}\right)$ and Sodium hydroxide $(\mathrm{NaOH})$ used for adjusting the $\mathrm{pH}$ obtained from School of Chemical and Food Engineering at Bahir Dar institute of Technology and

7. Fleshed part of the skin used for preparation of Activated carbon and determined the chromium and dyes before and after treatments obtained from Bahir Dar leather factory.

\subsubsection{Instruments}

The instruments used during the study were;

1. Oven dryer (DHG 9030) used to dry the sample after washing

2. Hot plate (HL 5360M) used to warm the sample, used to bring the samples to the desired temperature level

3. Furnace (HWS380, Ningbo, China) was used for the purpose of ignite the activated carbon to carried out activation process, volatile matter and ash content determination

4. Inductively Coupled Plasma-Optical Emission Spectroscopy (ICP-OES) (ICP-OES, ULTIMA-2) used to determine total chromium and chromium $\left(\mathrm{Cr}^{+6}\right)$ for the optimization and to determine the liquid effluent of chromium before and after the treatment of Bahir Dar leather industry

5. Uv-visible Spectroscopy (Perkin Elmer Lambda 35) used to determine the concentration of Mordant black and Azo dye and for scanning of specific wave length identification 


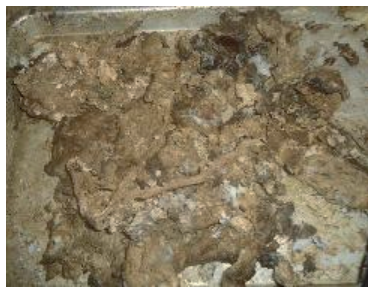

A

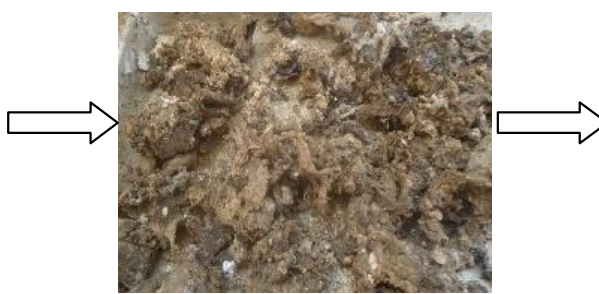

b

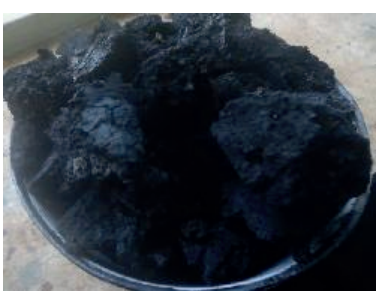

C

Figure 2: Flashed solid before washed (a) after washed \& dried at $105^{\circ} \mathrm{C}$ (b) and Charred after $\mathrm{H}_{2} \mathrm{SO}_{4}$ activation at $400^{\circ} \mathrm{C}$ for $12 \mathrm{hrs}(\mathrm{c})$.

6. Fourier transform infrared spectrometer (FT-IR) (Perkin Elmer spectrum-2) used to characterize the functional group of activated carbon made from fleshed parts the tannery solid wastes

7. BET (QUANTACHROME 11.03) were used for the determination of surface area, pore volume and pore size analysis of the activated carbon

8. $\mathrm{pH}$ meter (p125 Hanna) to adjust the solution $\mathrm{pH}$ to the desired point.

\subsection{Experimental description}

\subsubsection{Preparation of activated carbon by chemical activation}

The fleshed and trimmings parts of tannery solid wastes were used in this study (Figure 2). The collected wastes was cut into small pieces and washed with tap water to remove soil and dust. Before carbonization experiments, leather wastes were dried in an oven at $105^{\circ} \mathrm{C}$ to constant weight and then immerse in to concentrated sulfuric acid $\left(\mathrm{H}_{2} \mathrm{SO}_{4}\right)$ for $4 \mathrm{~h}$. The impregnated fiber was dried at $160^{\circ} \mathrm{C}$ till complete charring. The char was then washed with distilled water until the char was free from acid. After the activation was completed by heating for $12 \mathrm{~h}$ in a furnace at $400^{\circ} \mathrm{C}$, the resulting carbons was washed with distilled water and dried for $4 \mathrm{~h}$ at $100^{\circ} \mathrm{C}$ in a hot air oven. The dried adsorbent was then grounded and stored in separate vacuum desiccators for further studies.

\subsection{Characterization of activated carbon}

\subsubsection{Bulk density}

The activated carbon sample was packed in a previously weighed $25 \mathrm{~cm}^{3}$ specific gravity bottle by repeatedly tapping the bottle so that powder is filled up to the mark. The powder was poured in to the bottle then, weighed again. The difference in the weights gives the bulk density. The bulk density of powder was calculated using equation (1).

$$
\text { Bulk density }=\left[\frac{(\text { weight of powder taken in the bottle })}{25}\right]
$$




\subsubsection{Determination of $\mathrm{pH}$}

The determination of the points of zero charge of the sample was carried out as described. $50 \mathrm{~cm}^{3}$ of $0.01 \mathrm{M} \mathrm{NaCl}$ solution was placed in a closed Erlenmeyer flask. The $\mathrm{pH}$ was adjusted to a value between 2 and 12 by adding $\mathrm{HCl} 0.1 \mathrm{M}$ or $\mathrm{NaOH} 0.1 \mathrm{M}$ solutions. Then, $0.15 \mathrm{~g}$ of FTWAC sample was added and the final $\mathrm{pH}$ measured after $48 \mathrm{hrs}$ under agitation at room temperature. The $\mathrm{pH}$ points of zero charge is the point where the curve $\mathrm{pH}$ final vs. $\mathrm{pH}$ initial crosses line in to each other or $\mathrm{pH}$ initial $=\mathrm{pH}$ final (Rengaraj et al., 2001) [21].

\subsubsection{Moisture content}

One gram of the powdered air dried activated carbon powder was taken in a previously weighed crucible. The crucible was placed in an electric hot air oven maintained at about $110^{\circ} \mathrm{C}$. After one hour the crucible was taken out, cooled in desiccators and weighed again. The loss in weight of the powder reported on percentage basis gives moisture content in the sample.

$$
\mathrm{MC}=(\mathrm{Ww}-\mathrm{Wd}) / \mathrm{Ww} \times 100
$$

where MC: moisture content; Ww: wet weight of sample; Wd: dry weight of sample.

\subsubsection{Volatile matter}

About one gram of the powdered air dried activated carbon powder was taken in a previously weighed crucible. The crucible was placed in a muffle furnace maintained at about $950^{\circ} \mathrm{C}$. It was taken out after exactly 7 minutes. After first cooling in air, the crucible was cooled in a desiccators and weighed again. The loss in weight of the powder reported on percentage basis gives volatile matter content in the sample.

$$
\mathrm{Vm} \%=\left(\mathrm{W}_{\mathrm{d}}-\mathrm{W}_{\text {ash }}\right) / \mathrm{Ww} \times 100
$$

where VM: volatile matter; $\mathrm{Wd}$ : weight of dry sample; $\mathrm{W}_{\text {ash }}$ : weight of ash; $\mathrm{Ww}$ : weight of wet sample.

\subsubsection{Ash content}

The residual activated carbon powder from the above step was then heated in a muffle furnace at $750^{\circ} \mathrm{C}$ for about half an hour. After first cooling in air, the crucible was cooled in a desiccator and weighed again. The heating, cooling and weighing cycle was repeated till a constant weight was obtained. The residue is reported as ash on percentage basis.

$$
\operatorname{Ash} \%=\left(\mathrm{W}_{\mathrm{ash}} / \mathrm{W}_{\mathrm{w}}\right) \times 100
$$


Table 1: Absorbance vs Concentration.

\begin{tabular}{|c|c|c|}
\hline S. No. & Absorbance & Concentration $(\mathrm{ppm})$ \\
\hline 1 & 0.091 & 0.000 \\
\hline 2 & 0.125 & 0.025 \\
\hline 3 & 0.155 & 0.050 \\
\hline 4 & 0.237 & 0.100 \\
\hline 5 & 0.389 & 0.200 \\
\hline 6 & 0.352 & Sample (x) concentration \\
\hline
\end{tabular}

\subsubsection{Phenol number}

Solid phenol crystalline was used as stock solution. Then $100 \mathrm{~cm}^{3}$ of $30 \mathrm{ppm}$ solution of phenol was taken in a $250 \mathrm{~cm}^{3}$ leak proof reaction flask. The $\mathrm{pH}$ of the solution was adjusted to neutral by adding $0.1 \mathrm{~N} \mathrm{NaOH}$ or $0.1 \mathrm{~N} \mathrm{H}_{2} \mathrm{SO}_{4}$. 1 gram of activated carbon powder was added to it. The solution was equilibrated for 24 hours at room temperature followed by filtration and subsequent analysis of the filtrate for phenol concentration. The concentration of phenol was determined by Uv-vis spectrophotometric analysis for the color resulting from the reaction of phenol with 4-amino antipyrene at a wave length of $600 \mathrm{~nm}$.

A serious of known concentrations of phenol was prepared from stock solution. The absorbance of known concentration and unknown sample absorbance were determined at $600 \mathrm{~nm}$, then the absorbance concentration of sample was determined by using Origin software 8.0. The results were reported in the Table 1.

At $600 \mathrm{~nm}$ the absorbance of phenol complex was measured after passing through the activated carbon (adsorption) the absorbance was 0.352 abs. The concentration of phenol obtained from the calibration curve was $3.576 \mathrm{ppm}$.

\subsubsection{Surface area and porosity}

The BET surface area of activated carbon powder was determined by nitrogen adsorption desorption method. Nitrogen gas was allowed to adsorb on the powder at $77 \mathrm{~K}$. The nitrogen adsorption and desorption isotherms were used to determine parameters like surface area, pore volume and pore size.

The Brunauer-Emmett-Teller (BET) method is the most widely used procedure for the determination of the surface area of solid materials. The BET equation requires a linear plot of 1/[W(P0/P)-1] vs P/P0 which for most solids, using nitrogen as the adsorbate, is restricted to a limited region of the adsorption isotherm, usually in the $\mathrm{P} / \mathrm{P} 0$ range of 0.05 to 0.35 . This linear region is shifted to lower relative pressures for micro porous materials and in which $\mathrm{W}$ is the weight of gas adsorbed at a relative pressure $\mathrm{P} / \mathrm{P} 0$ on the adsorbent. The standard multipoint BET procedure requires a minimum of three points in the appropriate relative pressure range. The weight of a monolayer of adsorbate $\mathrm{Wm}$ can then be obtained from the slope $\mathrm{s}$ and intercept $i$ of the BET plot. All the equation ((5), (6), and (7)) mentioned used to calculate the amount of gas adsorbed on the surface or in free spaced of the adsorbent (FTWAC). 


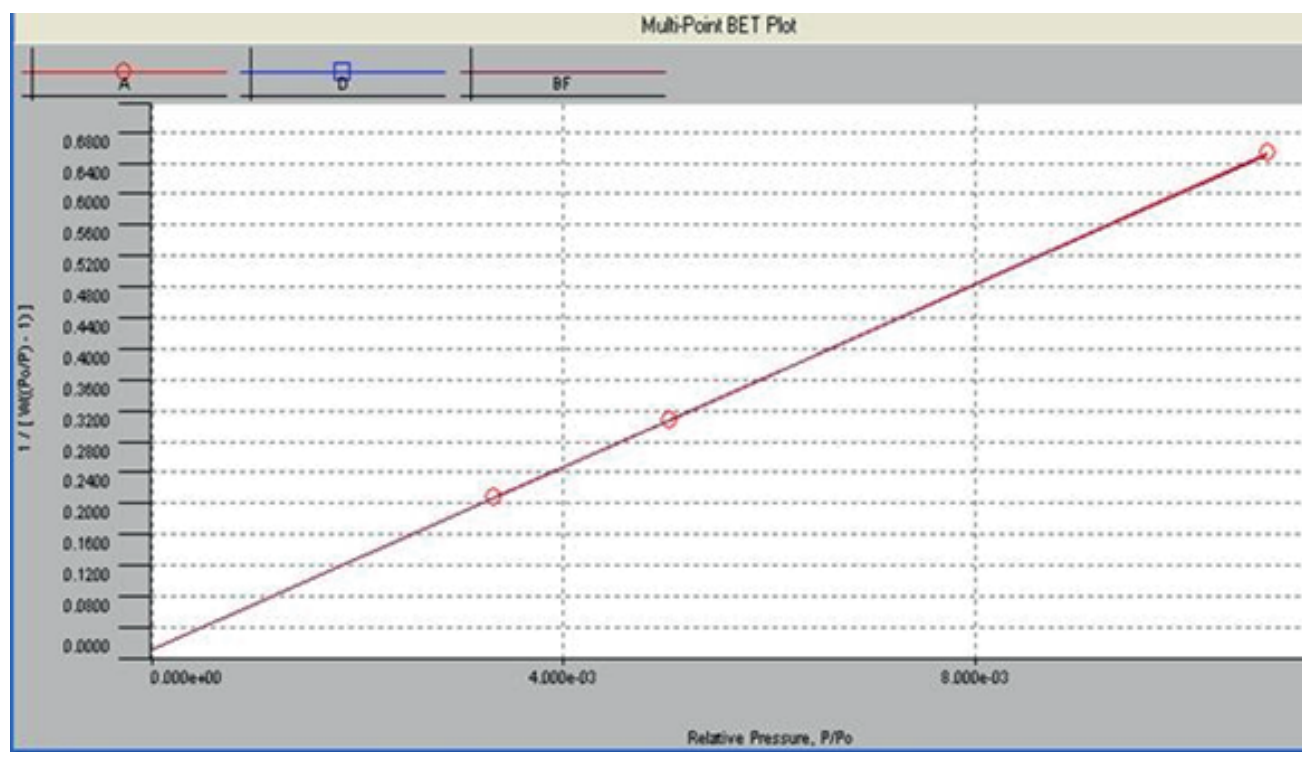

Figure 3: BET Surface area analysis of FTWAC sample.

$$
\begin{gathered}
\mathrm{St}=\frac{\mathrm{Wm} \mathrm{N} \text { Acs }}{\mathrm{M}} \\
\mathrm{Wm}=\frac{1}{\mathrm{~s}+\mathrm{i}}
\end{gathered}
$$

Specific Surface Area (S) is then, determined by total Surface area to sample weight (w)

$$
\mathrm{S}=\mathrm{St} / \mathrm{W}
$$

\subsubsection{FT-IR spectroscopy}

FT-IR is one of the key tools used to characterize the functional groups the surface of the carbon. Spectra analysis was done for tannery waste activated carbon using Fourier transform infrared spectrometer (FT-IR) in the range of $600-4000 \mathrm{~cm}^{-1}$. In this analysis, a tablet form of the sorbent was put in the sample disks then measured the spectra of the activated carbon.

\subsection{Optimization of chromium adsorption experiments}

$80 \mathrm{ppm}^{+6} \mathrm{r}^{+6}$ was taken for the purpose of optimization from stock solution obtained as equilibrium concentration as mentioned below. Adsorption experiments of treated activated carbon were separately placed in $250 \mathrm{ml}$ Erlenmeyer flask. $50 \mathrm{ml}$ of the adsorbate solution was added. Three factors (Dose, $\mathrm{pH}$ and Contact time) in four level, i.e., Dose $(0.5,1,1.5$ and 2 gram activated carbon), $\mathrm{pH}$ at (1, 3, 5 and 7) and contact time at (30, 60, 90, and 120 minutes) were used for the optimization but concentration, temperature, rpm and particle size $\left(80 \mathrm{ppm}, 30^{\circ} \mathrm{C}\right.$, $200 \mathrm{rpm}$ and $1 \mathrm{~mm}$ sieve size diameter)respectively were taken as constant. Using design expert (full factorial), $4^{3}$ ( 3 factors in 4 level) 64 runs were tested the chromium removal efficiency and adsorption capacity of tannery solid waste activated carbon for adsorption experiments of this 
Table 2: BET Surface area analysis.

\begin{tabular}{|c|c|c|}
\hline Relative pressure (P/Po) & Volume STP(cc/g) & $1 /[\mathrm{W}((\mathrm{Po} / \mathrm{P})-1)]$ \\
\hline $3.31900 \mathrm{e}-03$ & 12.7832 & $2.0843 \mathrm{e}-01$ \\
\hline $5.02300 \mathrm{e}-03$ & 13.0857 & $3.0868 \mathrm{e}-01$ \\
\hline $1.08190 \mathrm{e}-02$ & 13.4224 & $6.5198 \mathrm{e}-01$ \\
\hline \multicolumn{3}{|l|}{ BET summary } \\
\hline Slope $(s)=59.163$ & Intercept $(\mathrm{i})=1.182 \mathrm{e}-02$ & \\
\hline Correlation coefficient, $r=0.999999$ & C constant $=5005.272$ & \\
\hline Surface Area $=58.852 \mathrm{~m}^{2} / \mathrm{g}$ & Total Surface area $(\mathrm{St})=$ ? & \\
\hline
\end{tabular}

studies. It was placed in a rotary shaker (VRN-480, GEMMY Orbit Shaker, Taiwan) to facilitate mixing and allowed to equilibrate for a period from 30 to 120 minutes. All samples are filtered prior to analysis in order to minimize interference of the carbon fines with the analysis. The concentration of the supernatant solution was estimated to determine the residual hexavalent chromium concentration via concentration of standard solutions. The removal efficiency (R\%) of Hexavalent chrome was calculated for each run using the following expression.

$$
\mathrm{R}(\%)=[(\mathrm{Ci}-\mathrm{Ce}) / \mathrm{Ci}] * 100
$$

$\mathrm{Ci}$ and $\mathrm{Ce}$ were the initial and final concentration of hexavalent chrome in the solution. Under the experimental conditions, the adsorption capacity for each concentration of hexavalent chrome at equilibrium was determined by the following expression.

\subsubsection{Adsorption capacity}

$$
\mathrm{qe}(\mathrm{mg} / \mathrm{g})=[(\mathrm{Ci}-\mathrm{Ce}) / \mathrm{m}] * \mathrm{~V}
$$

$\mathrm{V}$ is the volume of solution (in liters) and $\mathrm{m}$ is the mass of adsorbent (in grams) used. The effect of adsorbent dose $(0.5,1,1.5$, and $2.0 \mathrm{~g}$ of FTWAC), contact time (30, 60, 90 and 120 minutes), initial $\mathrm{Cr}(\mathrm{VI})$ concentration $(80 \mathrm{mg} / \mathrm{l})$, temperature $\left(303.15^{\circ} \mathrm{k}\right)$ and $\mathrm{pH}(1,3,5$ and 7 ) was investigated. The concentration of $\mathrm{Cr}(\mathrm{VI})$ in the solutions before and after equilibrium was determined by ICP-OES and an helium flame with strict adherence to standard calibration guidelines. All the experiments have performed in triplicate and the mean values were reported by the instrument.

\subsubsection{Preparation of stock solution of chromium $\left(\mathrm{Cr}^{+6}\right)$}

The stock solution of $\mathrm{Cr}(\mathrm{VI})$ having concentration $1000 \mathrm{mg} / \mathrm{l}$ was prepared as a model pollutant by dissolving $2.8287 \mathrm{~g}$ dried crystalline of $\mathrm{K}_{2} \mathrm{Cr}_{2} \mathrm{O}_{7}$ in $1000 \mathrm{ml}$ of distilled water. This solution was diluted as required to obtain standard solutions containing 40-120 mg l-1 of $\mathrm{Cr}(\mathrm{VI})$. The $\mathrm{pH}$ of the solution was maintained at desired value by using dilute $0.5 \mathrm{~N} \mathrm{H}_{2} \mathrm{SO}_{4}$ and $0.5 \mathrm{~N} \mathrm{NaOH}$ solutions using digital $\mathrm{pH}$ meter before adsorption. 

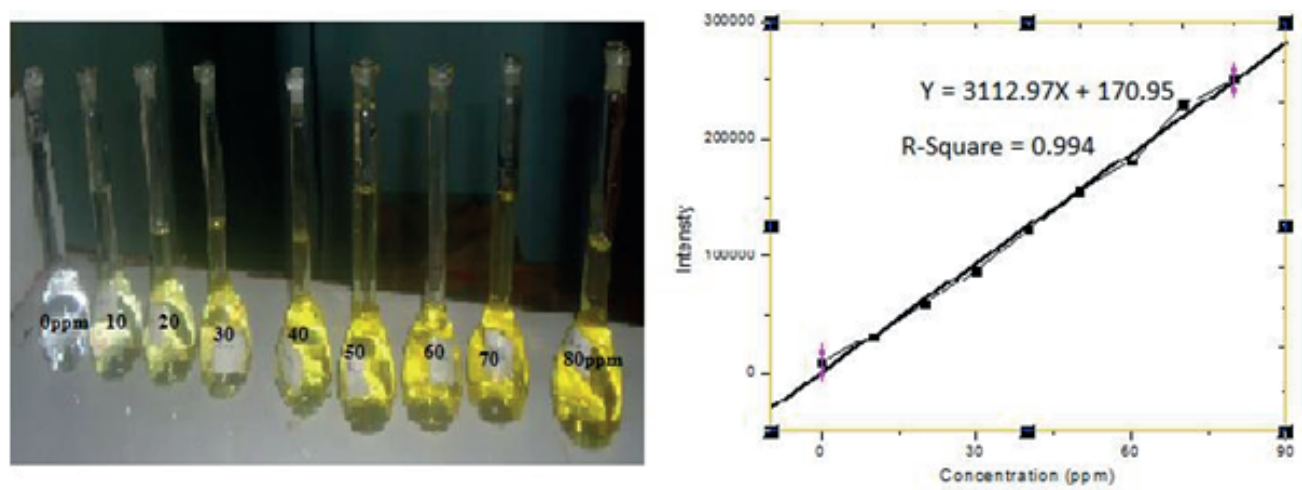

Figure 4: Standard solution and calibration curve.

\subsubsection{Equilibrium uptake experiments}

Batch equilibrium experiments were carried out using FTWAC as adsorbents. Potassium dichromate $\left(\mathrm{K}_{2} \mathrm{Cr}_{2} \mathrm{O}_{7}\right)$ was used as the source of $\mathrm{Cr}(\mathrm{VI})$ in the synthetic wastewater. The $\mathrm{Cr}$ stock solution $(1000 \mathrm{mg} / \mathrm{l})$ was prepared by dissolving $2.8287 \mathrm{~g}$ of $\mathrm{K}_{2} \mathrm{Cr}_{2} \mathrm{O}_{7}$ in $1000 \mathrm{ml}$ of deionized water. A series of flasks containing dichromate solutions of varying concentrations from 10 to $120 \mathrm{mg} / \mathrm{l}$ prepared from the stock solution. Adjustment of $\mathrm{pH}$ was carried out using $0.1 \mathrm{~N}$ $\mathrm{NaOH}$ and/or $0.1 \mathrm{~N} \mathrm{H}_{2} \mathrm{SO}_{4}$. Agitation of the system under investigation was carried out on a rotary shaker. To maximize $\mathrm{Cr}$ removal by the adsorbent, batch experiments were conducted at ambient temperature using the optimum conditions of all pertinent factors, such as dose, $\mathrm{pH}$, and contact time. Subsequent adsorption experiments were carried out with only optimized parameters. Adsorption isotherm tests were also carried out in the reaction mixture consisting of $2 \mathrm{~g} / \mathrm{l}$ of adsorbent and $100 \mathrm{ml}$ of Cr solution with varying chromium concentration from 10 to $120 \mathrm{mg} / \mathrm{l}$. The point at which no further uptake $\mathrm{Cr}(\mathrm{VI})$ concentration due to adsorption was used as equilibrium concentration.

\subsubsection{For standard calibration}

Solution of potassium di chromate $\left(\mathrm{K}_{2} \mathrm{Cr}_{2} \mathrm{O}_{7}\right)$ were prepared seriously $0,10,20,30,40,50,60$, $70,80 \mathrm{ppm}$

\subsubsection{Effluents of total Chromium and $\mathrm{Cr}^{+6}$ before $\&$ after treatment}

Determination of total chromium and $\mathrm{Cr}^{+6}$ of the sample were digested for $3 \mathrm{hrs}$ using sulphuric acid, then by cooling and filtering the total chromium content were reported as in Table 4, 5, but $\mathrm{Cr}^{+6}$ were need to make complex using complexing agent as stated below.

Principle of the method: Under acidic conditions hexavalent chromium reacts with sdiphenylcarbazide (DPC) to form a reddish violet colored complex resulting from the reaction of hexavalent chromium with s-diphenylcarbazide. The chromate oxidizes DPC to diphenylcarbazone (DPCO). The determination of chromium with the derivatizing agent, $0.5 \mathrm{ml}$ of DPC were added, to enables the speciation of chromium without a previous separation step, because 
Table 3: Three factor in four levels on removal \& adsorption capacity of Chromium.

\begin{tabular}{l|c|c|c|c|c|c|c|c|} 
Factor & Name & Units & \multicolumn{3}{|c|}{ Levels 4} & Responses & Removal efficiency (R1) \\
\hline A & Dose & Gram & 0.5 & 1 & 1.5 & 2 & \\
\hline B & pH & - & 1 & 3 & 5 & 7 & Adsorption capacity (R2) \\
C & Contact time & minutes & 30 & 60 & 90 & 120 &
\end{tabular}

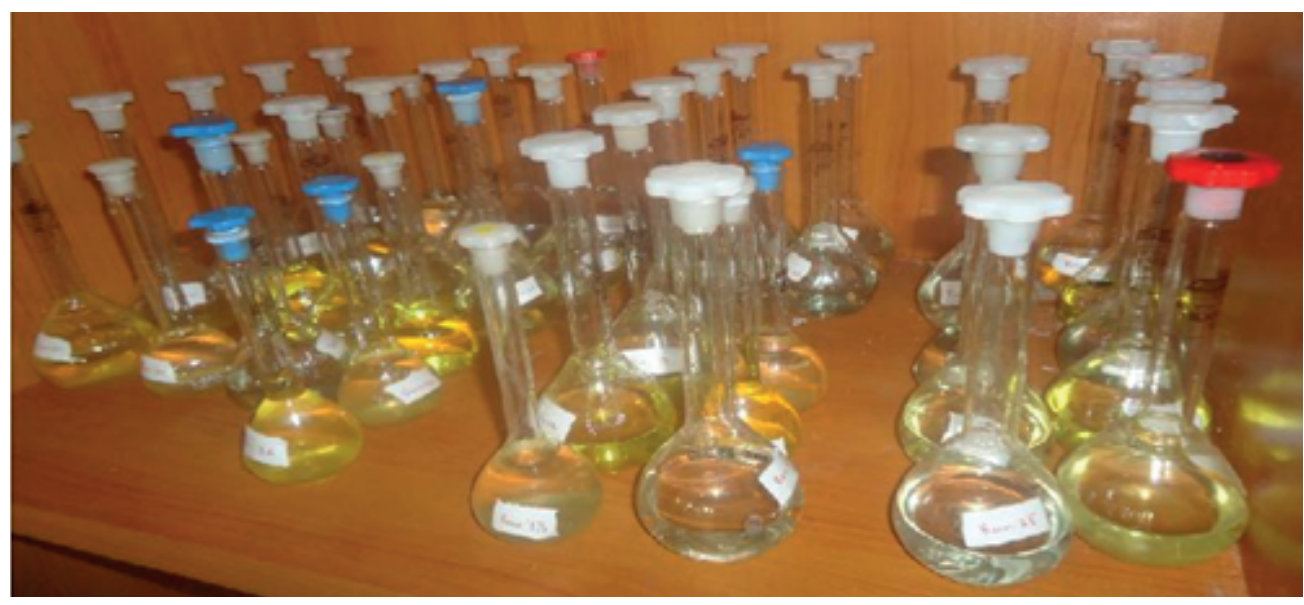

Figure 5: Optimization of chromium after treatment.

this reaction is selective for $\mathrm{Cr}(\mathrm{VI})$. Acid solutions of potassium dichromate are colored and the intensity of this color is proportional to the concentration of the dichromate anion in solution.

The calibration curve using origin software 8.0 the R-square value is $99.4 \%$ almost near to one therefore standard solution preparation almost correct, because the curve must be straight line and the values of R-square must near to unit for the acceptance of the ICP-OES instruments results.

\subsubsection{The factor affecting for the two response analysis}

See Table 3 and Figure 5.

\subsection{Optimization of mordant black-11 and Azodyes adsorption experiments}

Adsorption experiments are carried out by agitating 1 gram of Activated carbon in $50 \mathrm{~mL}$ of dye solutions (Mordant black and Azodyes) of concentrations ranging from 40 to $160 \mathrm{mg} / \mathrm{L}$ in $100 \mathrm{~mL}$ stoppered conical flasks at $200 \mathrm{rpm}$ and at $30^{\circ} \mathrm{C}$ in a thermostatted water bath shaker to reach equilibrium. The adsorbent was separated by filtration using Whattman filter paper no. 42 and the concentrations of residual dyes Mordant Black (MB) and Azodyes (AD) others are estimated in the supernatant spectrophotometrically by determining the absorbance of the solution at $547.3 \mathrm{~nm}$, and $491.56 \mathrm{~nm}(\mathrm{kmax})$, respectively, using a UV-Vis spectrophotometer (Perkin Elmer Lambda 35).The optimization results for removal efficiency and adsorption capacity was 
quantified as the (Decoloring Efficiency) DE (\%). The absorbance of original liquor was taken as A0 and that of filtrate was taken as A.

$$
\text { Calculation of } \mathrm{DE}(\%)=(\mathrm{A} 0-\mathrm{A}) / \mathrm{A} 0 \times 100 \%
$$

Different concentrations of individual dye solutions such as Mordant Black-11 and Azo dyes (red) were prepared with distilled water. The concentrations of dyes in solutions were determined before and after adsorption using Perkin-Elmer UV-visible spectrophotometer. The amount of dye adsorbed and adsorption efficiency were calculated as mentioned above in equation (10).

\subsubsection{Preparation stock solution}

Mordant black-11 dye and Azo dyes stock $\left(1000 \mathrm{mgl}^{-1}\right)$ and standard solution were preparation Procedure: Mordant black dye and Azo dyes were dried at $110^{\circ} \mathrm{c}$ for 2 hours before use. All of the Mordant black dye and Azo dyes solution were prepared with double distilled water.

(i) A stock solution of $1000 \mathrm{mgl}^{-1}$ were prepared by dissolving 1 gram Mordant black-11 dye in $1000 \mathrm{ml}$ double distilled water and 1 gram Azo dye in $1000 \mathrm{ml}$ double distilled water each in different $1000 \mathrm{ml}$ volumetric flask. These give the stock solution. The experimental serious solution were prepared by diluting the stock solution of taking 40,80,120, and $160 \mathrm{ml}$ $\&$ double distilled water were added to mark of $1000 \mathrm{ml}$ volumetric flask then the concentration of the serious solution become ( $40 \mathrm{ppm}, 80 \mathrm{ppm}, 120 \mathrm{ppm}$, and $160 \mathrm{ppm}$ ) of which used for the optimization.

\subsubsection{Optimization of Mordant black-11 dye}

Mordant black-11 dyes are one of azo dye group of which metal-complexes used to make the leather black in color. In this study three factors (concentration, $\mathrm{pH} \&$ contact time) in 4 label were examined for the optimization as shown in Figure 6 . The activated carbon made from flashed parts of tannery is used to examine the removal efficiency and adsorption capacity for optimization of mordant black-11.

\subsubsection{Runs for optimization}

The figure here below shows that the black colored dye after pass through the activated carbon and filtered for each combination factor.

\subsubsection{Optimization of red color Azo dye}

Here also the optimization of red color azo dye was examined experimentally. Red color azo dye in leather industry was certainly used as coloring agent. In this work the optimization were carried out by choosing three factors (concentration, $\mathrm{pH}$ and contact time) each in four levels as shown in Figure 8. 

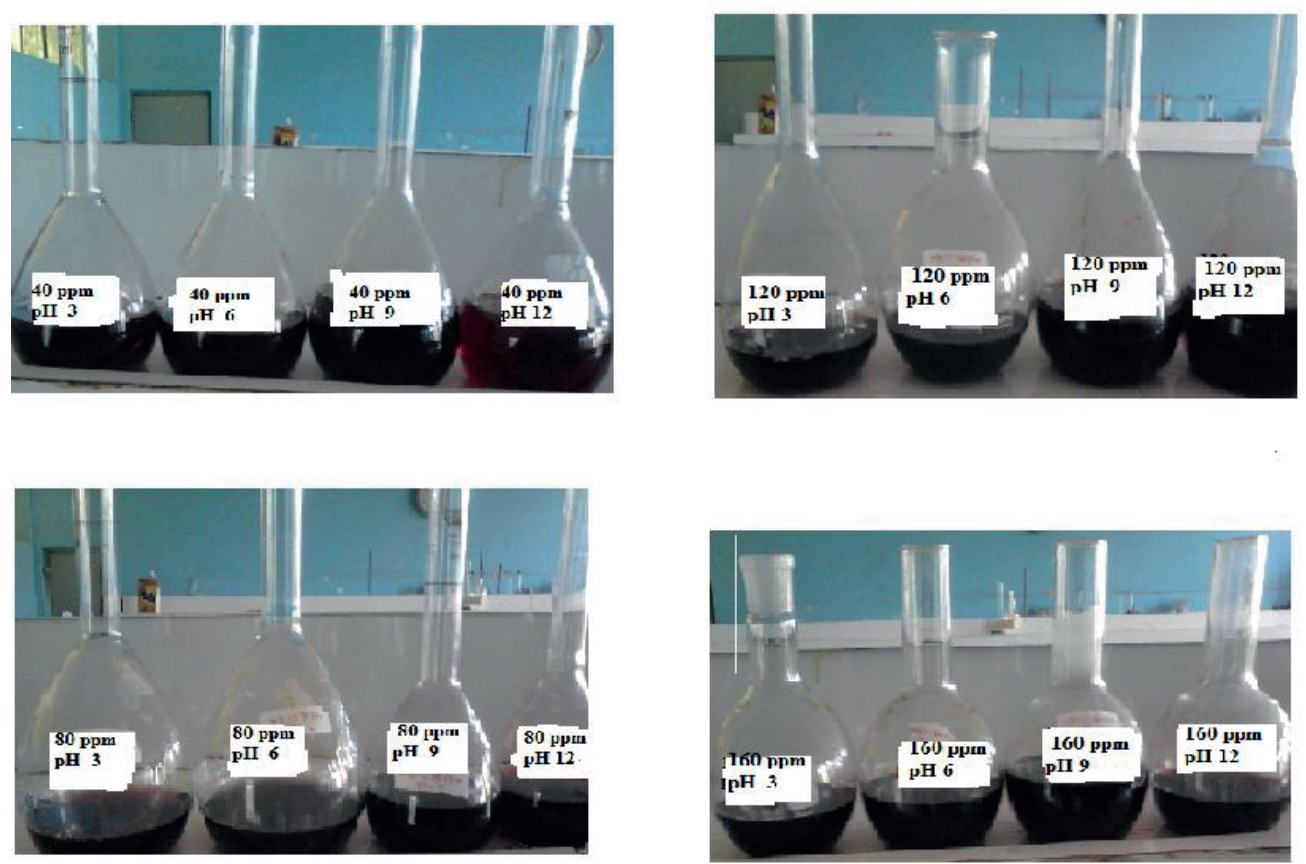

Figure 6: Optimization of mordant black-11 dye.
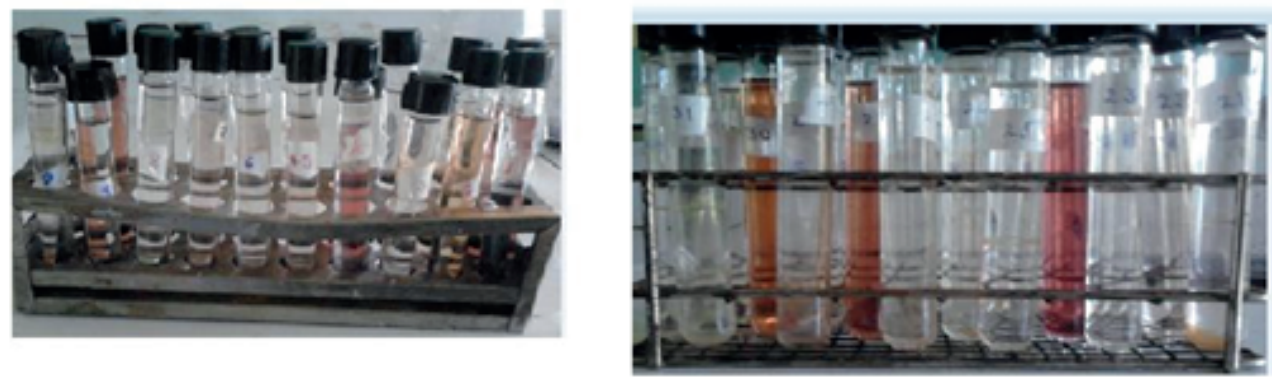

Figure 7: Results after treatments.
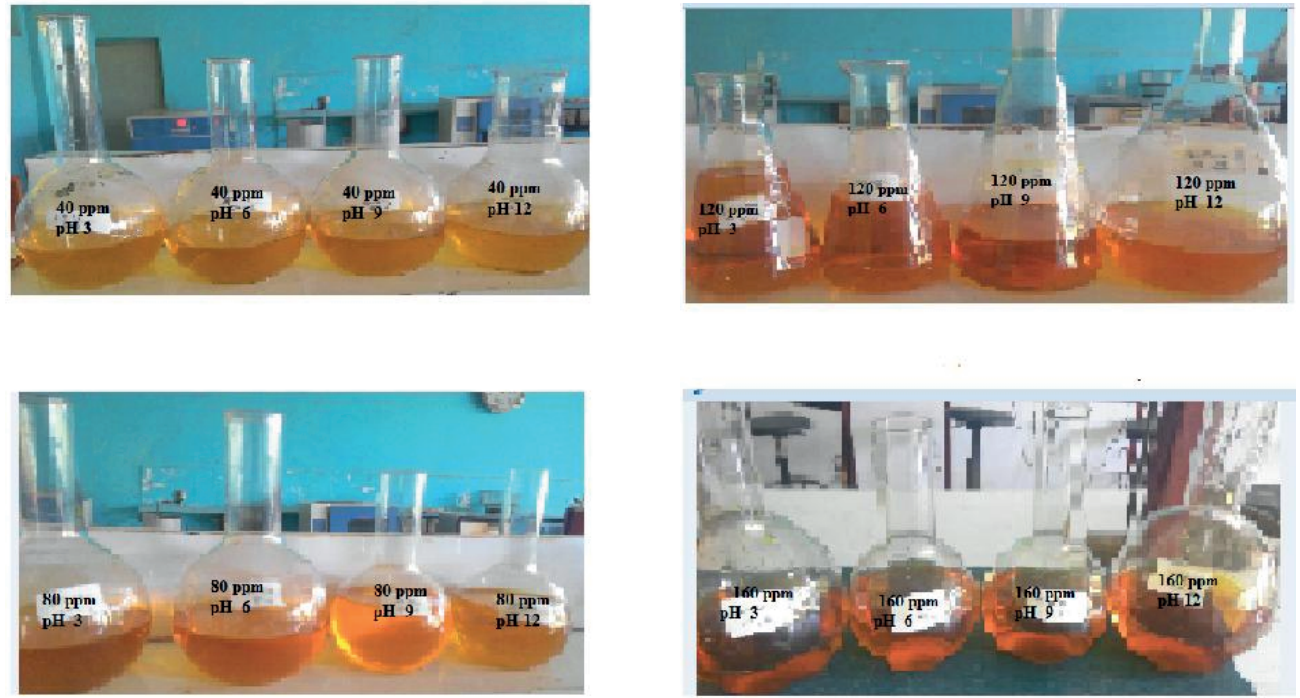

Figure 8: Optimization of red azo dye. 


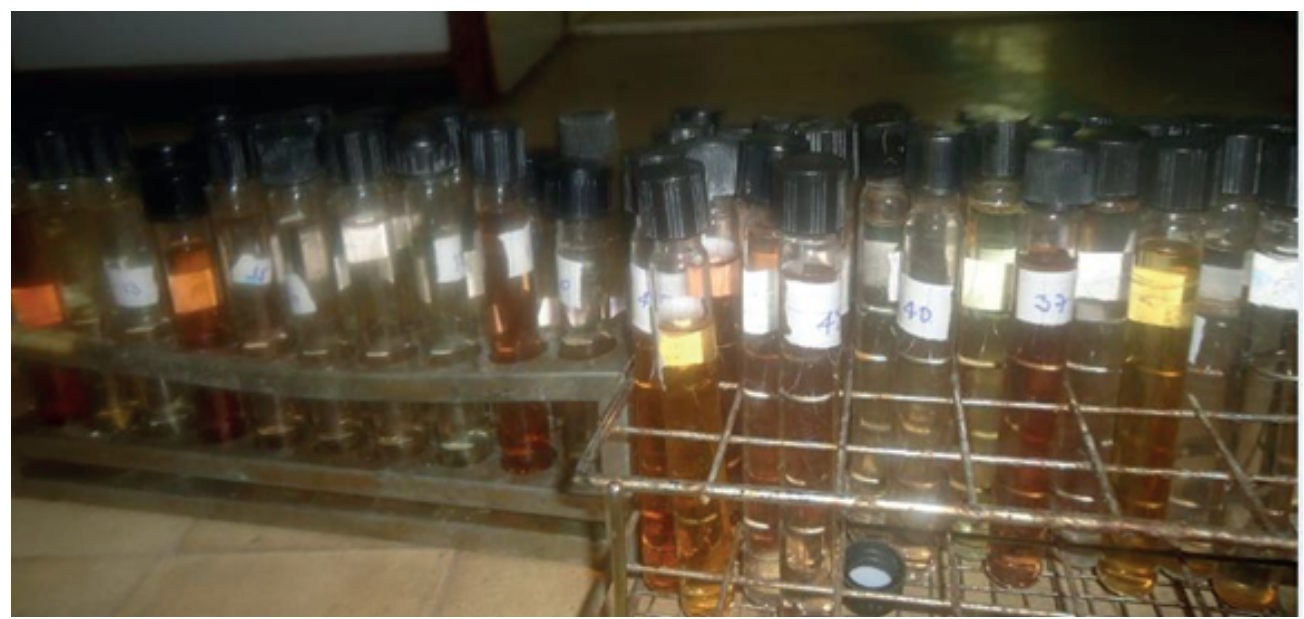

Figure 9: Red color azo dye optimizations after adsorption.

\section{Results and Discussion}

This thesis work mainly focused on the characterization of activated carbon made from fleshed part of the skin and optimization of chromium, mordant black and azo dye, removal efficiency and adsorption capacity of the activated carbon synthesized from fleshed part of skin were analyzed.

\subsection{Characterization of Fleshed Tannery Waste Activated carbon (FTWAC)}

After the acid activation process performed, then different characterization techniques were cried out experimentally.

\subsubsection{Bulk Density Measurements}

Density characteristics can also be a major consideration for specific applications. Densities vary with the raw materials that is a fewer quantity of carbon with a lower density and a higher carbon containing material with higher density. Therefore, the difference in densities of the activated carbons can be attributed to differences in the carbon origin. The densities observed in this work which are given in Table 4 are in close agreement with values of 0.35 to $1.2 \mathrm{~g} / \mathrm{m}^{3}$ as reported in other literature (Elinge et al., 2011) [10].

\subsection{2. pH measurement}

The $\mathrm{pH}$ of the activated carbon was matter on the activation methods, in this study acid activation was implemented. Therefore, the active sight of the activated carbon prepared was showing in acidic range this may be caused due to acidic activation methods. 


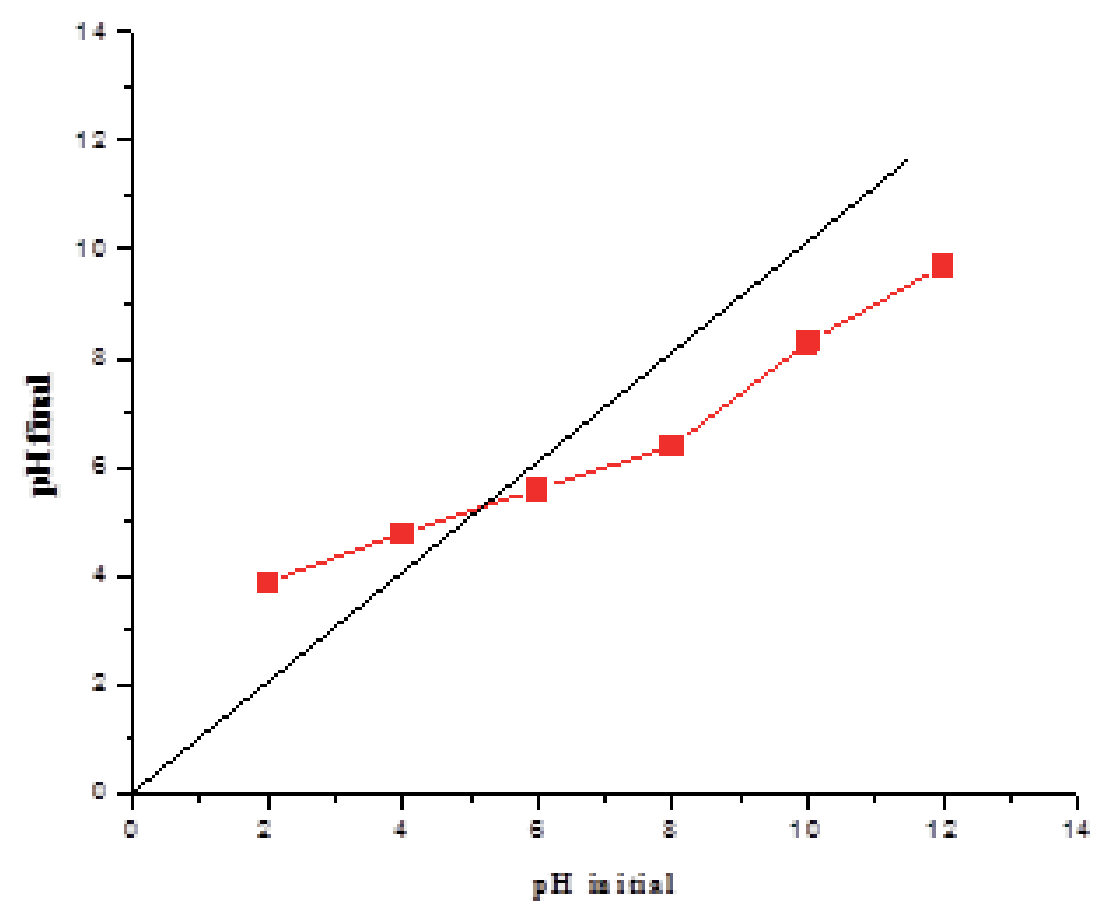

Figure 10: $\mathrm{pH}$ of point of zero charge of FTWAC.

\subsubsection{Moisture content}

Moisture content is one of the most commonly measured properties of materials due to a number of reasons mainly for the purpose of hydrophobicity of activated carbon. Here some of the activated carbon would highly love water and others may love in less degree, since the ability of water attracting would determine the surface phenomena, most often the surface is occupied by water the ability of removal efficiency and adsorption capacity for other incoming species would decreased. The moisture content values of the prepared activated carbon samples were very small which is suitable for the purpose of removal efficiency, since its surface is not occupied by water as reported in Table 4 .

\subsubsection{Volatile Matter}

The volatile matter of activated carbon made from fleshed parts of tannery solid waste samples were weighed before and after igniting at $950^{\circ} \mathrm{C}$ are reported in Table 4.

\subsubsection{Ash Content}

The ash content was an important properties of activated carbon because the more the ash content, the activated carbon became soft and more compacted and the chance of porous decrease but the activated carbon with less amount of ash content would have more strength and more porous. Therefore, acid activation is one of the methods used to reduce the ash content during the activation. The ash contents of the activated carbon made from fleshed part of tannery solid wastes were reported in Table 4. 
Table 4: Physico-Chemical parameters of activated carbon from flashed parts of tannery solid wastes.

\begin{tabular}{|l|c|c|c|}
\hline S.No. & Characteristics & Units & Values \\
\hline 1 & Bulk Density & $\mathrm{g} / \mathrm{cm}^{3}$ & 0.6104 \\
\hline 2 & $\mathrm{pH}$ & - & 5.3 \\
\hline 3 & Moisture content & $\%$ & 4 \\
\hline 4 & Volatile matter & $\%$ & 41 \\
\hline 5 & Ash Content & $\%$ & 40 \\
\hline 6 & Phenol number & $\mathrm{mg} / \mathrm{g}$ & 3.5757 \\
\hline
\end{tabular}

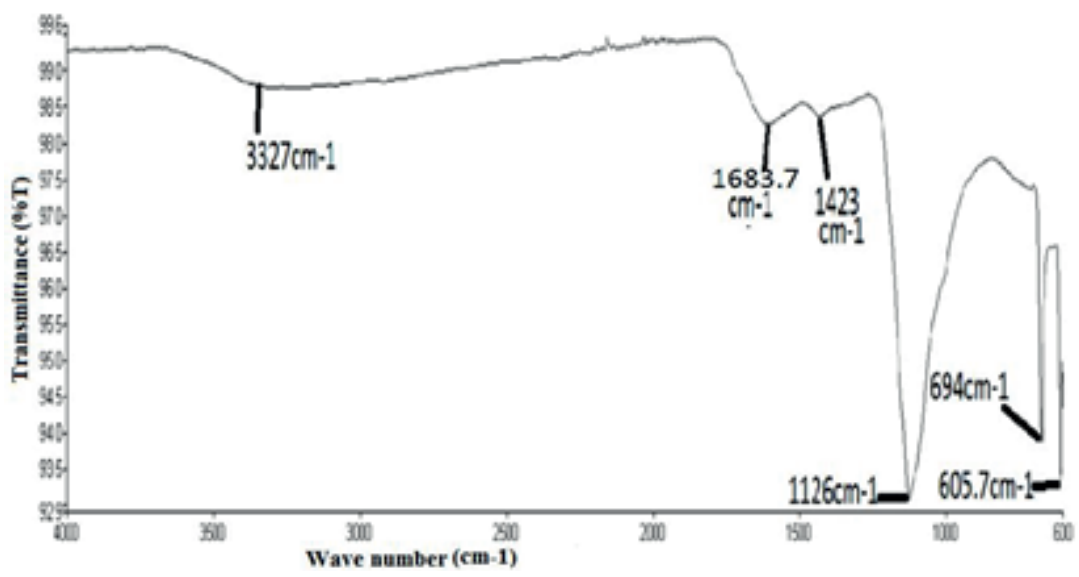

Figure 11: FT-IR spectra analysis.

\subsubsection{Phenol Number}

The main importance of phenol number determination in this work was to know the ability of the activated carbon to remove the amount odor and test from the wastes. Therefore, the amount of activated carbon required for $88.1 \%$ removal of phenol. This indicates the ability to remove taste and odor was very high. The result obtained from the experiment is shown in Table 4.

\subsubsection{Surface area and porosity}

One of the most important properties of activated carbon is the surface area and its surface porosity hence the adsorption of sample would be more and more as the surface area and porosity became increase. The greater surface area has the greater tendency to absorb more species of adsorbent. The surface area obtained $535.02 \mathrm{~m}^{2} / \mathrm{g}$ from the sample analyzer (surface area and porosity analyzer). Even though the surface area recorded by BET analyzer was good, but as compared to the other activated carbon originated from agricultural wastes studied by other researcher was moderate surface area. 
Table 5: FT-IR results interpretation.

Wave no. $\left(\mathrm{cm}^{-1}\right)$
$3500-3200$
$1760-1665$
$1470-1450(\mathrm{~m})$
$1320-1000(\mathrm{~s})$
$700-610(\mathrm{~b}, \mathrm{~s})$
$690-515(\mathrm{~m})$

Bond
O-H, stretch, H-bonded
$\mathrm{C}=\mathrm{O}$, stretch
$\mathrm{C}-\mathrm{H}$ bend
$\mathrm{C}-\mathrm{O}$ stretch
$-\mathrm{C}$ (triple bond) $\mathrm{C}-\mathrm{H}: \mathrm{C}-\mathrm{H}$ bend
$\mathrm{C}-\mathrm{Br}$ stretch

\begin{tabular}{|c|}
\hline Experimental Results \\
\hline $3327 \mathrm{~cm}^{-1}$ \\
\hline $1683.7 \mathrm{~cm}^{-1}$ \\
$1423 \mathrm{~cm}^{-1}$ \\
$1126 \mathrm{~cm}^{-1}$ \\
\\
$694 \mathrm{~cm}^{-1}$ \\
$605.7 \mathrm{~cm}^{-1}$
\end{tabular}

\section{Functional group}

Acid, Alcohol, Phenol

Carbonyl(general)

Alkanes

Alcohols, Carboxylic Acids,

Esters, Ethers

Alkynes

Alkyl halides

\subsubsection{FTIR Spectroscopy}

The functional groups of synthesized activated carbon from the tannery were identified with spectral analysis as follows.

From the experimental results of FT-IR, interpretations the sample of activated carbon has showed acidic functional group. The broad band at $3327 \mathrm{~cm}^{-1}$ showed due to unknown impurity the intensity of the peak was weak. Due to acidic activation methods applied the results of FTIR for the synthesized activated carbon have acidic active sight.

\subsubsection{Optimization of Chromium on Adsorption}

In this study mainly focused on the optimization of removal efficiency and adsorption capacity of the activated carbon synthesized from fleshed parts of tannery solid wastes. Here, the factor that affect the chromium adsorption were Dose, $\mathrm{pH}$ and Contact time are mainly affect the results of removal efficiency and adsorption capacity but keeping concentration, temperature, rpm and particle size $\left(80 \mathrm{ppm}, 30^{\circ} \mathrm{c}, 200 \mathrm{rpm}\right.$ and $1 \mathrm{~mm}$ sieve size diameter) were taken as constant. The actual elemental chromium $\left(\mathrm{Cr}^{+6}\right)$ concentration determination were carried out by varying the three factors, after adsorption were carried the results were determined using Inductively Coupled Plasma Optical Emission Spectrometer. The results obtained after passing the solution through the activated carbon were recorded in ppm (parts per million). Therefore, the results of 64 run for the optimization were carried the initial concentration of $80 \mathrm{ppm}$ were recorded by varying the three factors (Dose, $\mathrm{pH}$ and Contact time).

\subsection{The effects of factor on removal efficiency and Adsorption capacity}

The removal efficiency and adsorption capacity of hexavalent chromium is studied in terms of: the effect of contact time, dosage and $\mathrm{pH}$.

Taking the maximum dose 2 gram and 120 minutes contact time the $\mathrm{pH}$ effect on removal efficiency and adsorption capacity was studied. The $\mathrm{pH}$ of solution has influence on the extent of adsorption removal efficiencies of chromium (VI) by prepared activated carbon at different $\mathrm{pH}$ values $(1,3,5$ and 7$)$ are shown in figure below. From the figure, it is observed that chromium 

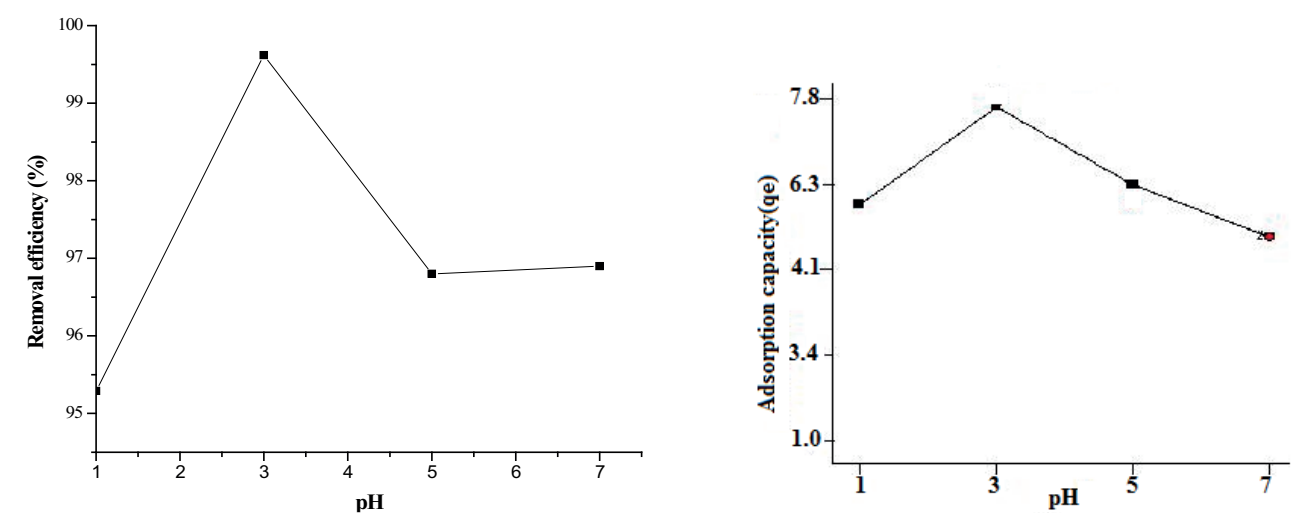

Figure 12: Effects of $\mathrm{pH}$ on removal efficiency $(\% \mathrm{R}) \&$ adsorption capacity (qe): dose $=2 \mathrm{~g}, \mathrm{t}=2 \mathrm{hrs}$ and $\mathrm{C}=2 \mathrm{~g} / \mathrm{l}$.
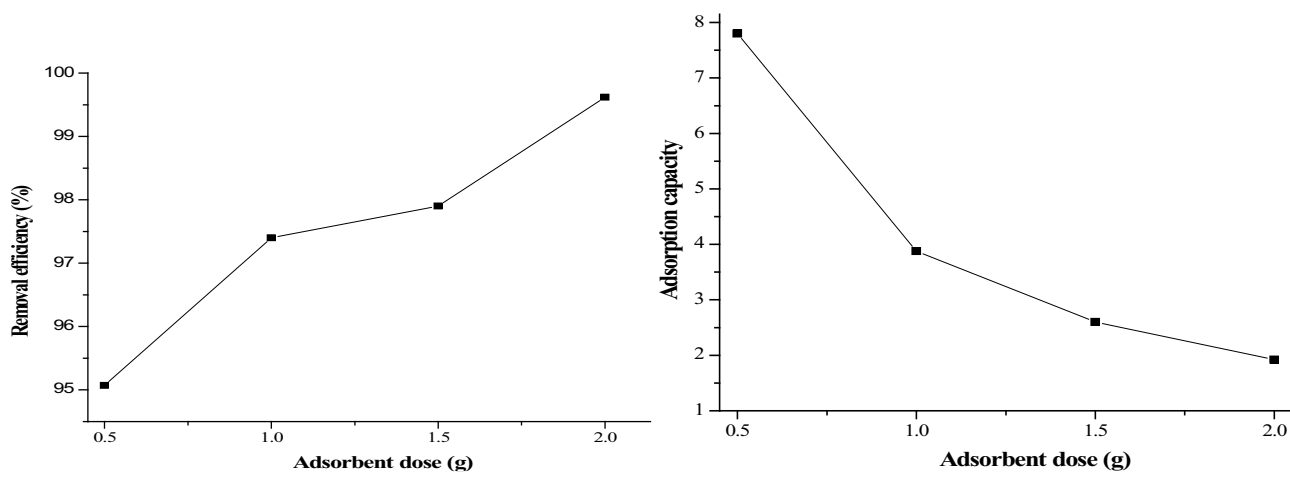

Figure 13: Effects of dose on removal efficiency (R1) \& adsorption capacity (R2): $\mathrm{pH}=3, \mathrm{t}=2 \mathrm{hrs} \& \mathrm{C}=2 \mathrm{~g} / \mathrm{l}$.

(VI) is removed more effectively in acidic range. As $\mathrm{pH}$ increases, the removable efficiency decreases appreciably. This is due to the precipitation of carbon surface by nucleation. The optimum $\mathrm{pH}$ for prepared carbon is $\mathrm{pH} 3$ and maximum removal efficiency and adsorption capacity were 99.7 and 7.8 respectively.

The effect of adsorbent dosage is studied and graph of removal efficiency and adsorption capacity on chromium versus dosage is plotted as shown in figure above. From the graph it is observed that, as the dosage of carbon increases, amount of removal efficiency increases but adsorption capacity decreases sharply and attains equilibrium. The dosage, at which minimum adsorption capacity attained, is taken as optimum dosage. After this not much change is observed even after increase in the amount of carbon dosage because of the results of electrostatic interactions and interference of binding site which have an influence to reduce adsorbent densities (Ahmed Said et al., 2013) [3]. Basically the more the active sites would cause higher chance of the removal efficiency but in case of adsorption capacity, it occurs so because the adsorptive capacity of adsorbent available was not fully utilized at a higher adsorbent dosage in comparison to lower adsorbent dosage. Therefore, it might be possible that adsorption capacity decreases as adsorbent dosage increases. Moreover, the increase in active sites for aqueous 

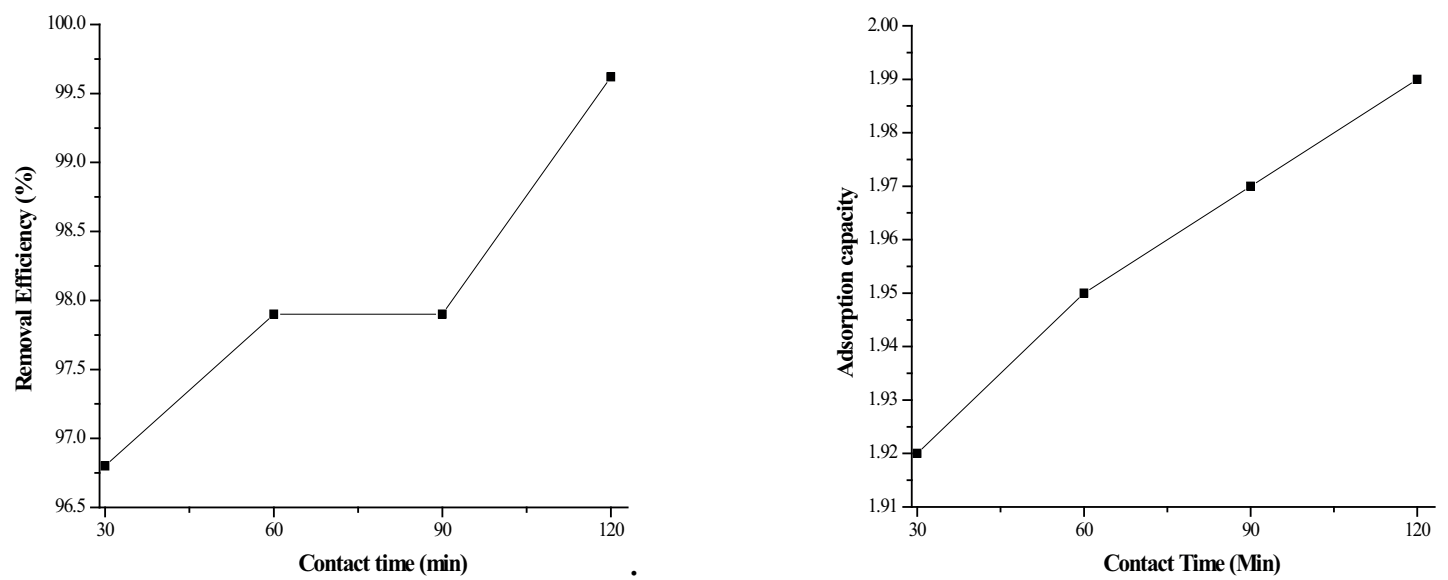

Figure 14: Effects of contact time on removal efficiency $(\% R 1) \&$ adsorption capacity $(R 2):$ dose $=2 \mathrm{~g}, \mathrm{pH}=3$ and $\mathrm{C}=2 \mathrm{~g} / \mathrm{l}$.
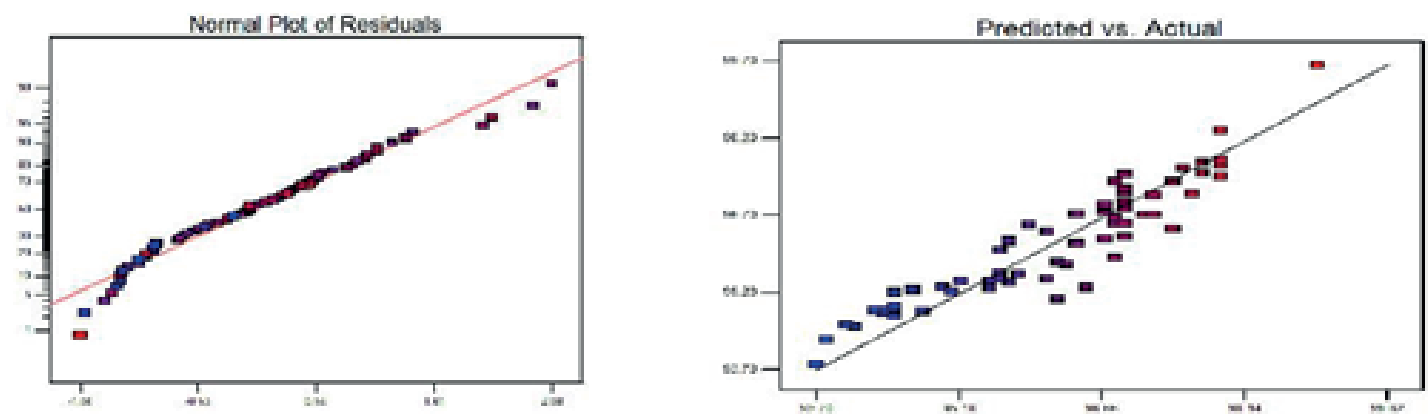

Figure 15: Normalized \& Predicted vs Actual plots for removal efficiency.
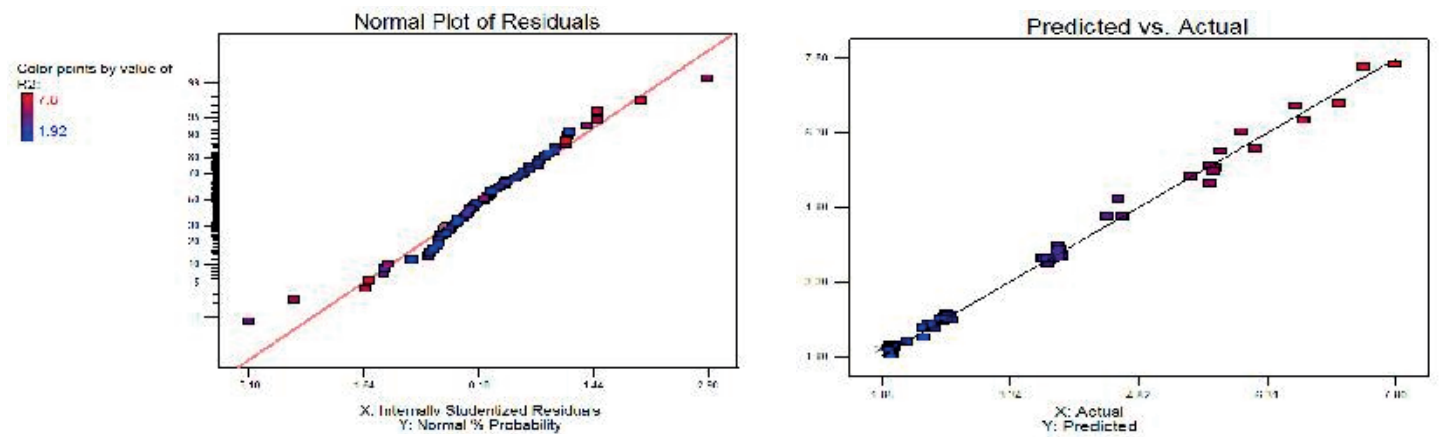

Figure 16: Normalized \& Predicted vs Actual plots on adsorption capacity.

solution concentration and the solute concentration on the surface area of activated carbon become unsaturated (Adhena et al., 2014; Devi et al., 2012; Cheng and Yang, 1975; Huang and $\mathrm{Wu}, 1975$; Montanher et al., 2005) [2, 7, 16, 18, 20]. 
Table 6: Total chromium and $\mathrm{Cr}(\mathrm{IV})$ before and after treatment.

\begin{tabular}{l|c|c}
\hline Treatments & Before & \multicolumn{1}{c}{ After } \\
\hline Total chromium & $78.7 \mathrm{ppm}$ & $7.083 \mathrm{ppm}$ \\
\hline $\mathrm{Cr}^{+6}$ (using DPC) & $2.93 \mathrm{ppm}$ & $0.26 \mathrm{ppm}$ \\
\hline
\end{tabular}

The effect of contact time has greater influence in the adsorption process. The effect of contact time on removal efficiency and adsorption capacity of chromium (VI) from synthesized activated carbon at $\mathrm{pH} 3$ are shown in figure below. Its clearly observed that removal efficiency increases as contact time increases but adsorption capacity increases until to optimum time and remain constant, no more increases or decreases due to the increase in surface area.

\subsection{Normalized plot \& predicted/Actual on removal and adsorption}

Here, mainly the normalized and predicted vs actual plots shows that the distribution of the sample from the line of expected region. If some of the sample out of the normalized point it is out layers.

\subsubsection{Effluents total Chromium and $\mathrm{Cr}^{+6}$ before $\&$ after treatment}

The mean concentrations of chromium in the liquid effluents were higher than the recommended maximum limit by WHO and EPA which is $0.1 \mathrm{ppm}$ for inland surface water and $0.05 \mathrm{ppm}$ for portable water. Therefore, it is advisable to treat the discharge effluents using the activated carbon, since the amount after treatment reduced over $90 \%$ of the toxic substances.

\subsection{Optimization of mordant black-11dye}

Three factors (concentration, $\mathrm{pH} \&$ contact time) and four labels for each treatment of different condition were analyzed using design expert software 7:00.

\subsubsection{Optimum of process parameter results}

Full factorial design was used for the optimization of experimental work. Under this operational parameter three conditions were sated as a factor of input criteria. Therefore, out of 64 run 10 solution were found for the optimal values in numerically. The optimum values for dye removal efficiency and adsorption capacity were carried and the higher desirability values are selected (0.963), so then, concentration $120 \mathrm{ppm}, \mathrm{pH}$ 9, and contact time 120 most selected one. Even though 10 solutions found for the optimization out of 64 run using design expert software the desirability was decreased both removal efficiency and adsorption capacity. Therefore, the higher values of desirability were chosen for the optimization of single effects and the interaction effects throughout this work. 


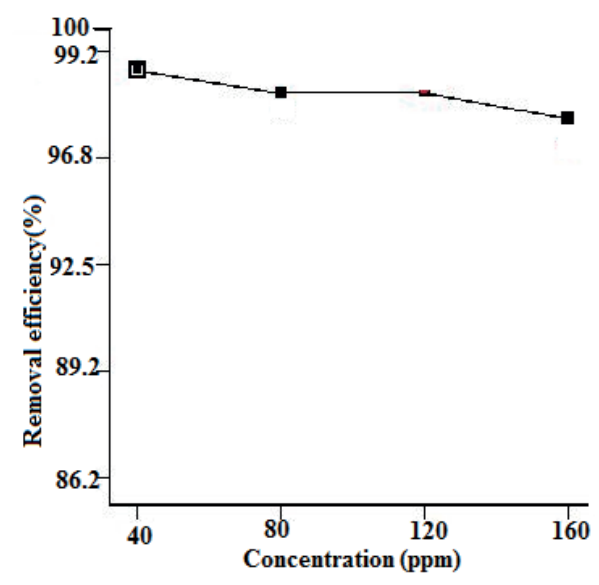

a) dye removal efficiency

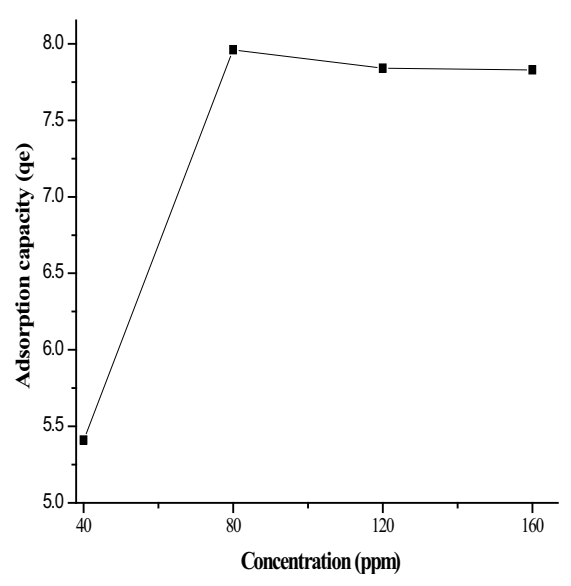

b) adsorption capacity

Figure 17: Effects of concentration on dye removal efficiency \& adsorption capacity (qe): dose $=2 \mathrm{~g}, \mathrm{t}=2 \mathrm{hrs}$ and $\mathrm{pH}=9$.

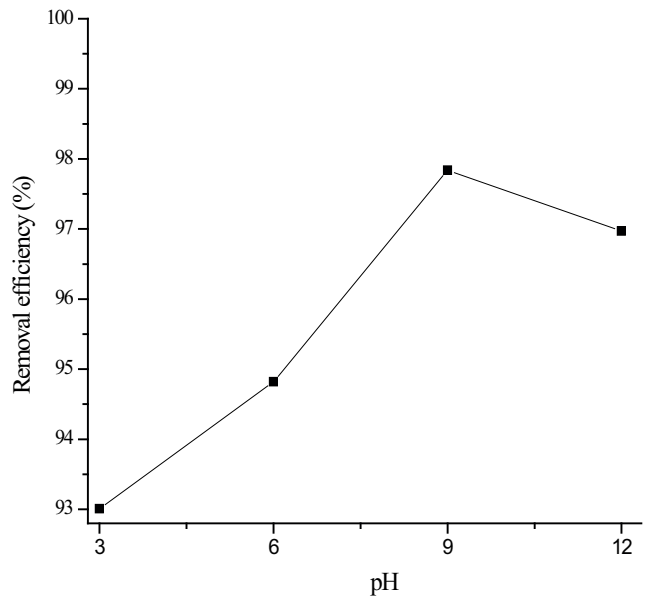

a) dye removal efficiency

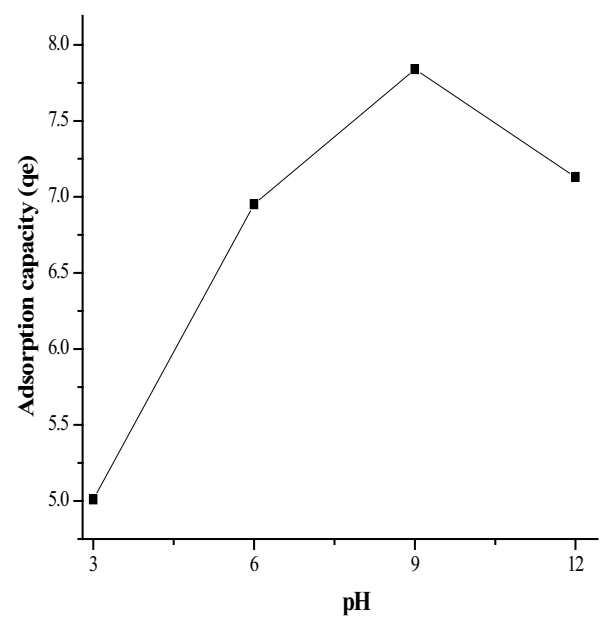

b) adsorption capacity

Figure 18: Effects of $\mathrm{pH}$ on dye removal efficiency \& adsorption capacity: dose $=2 \mathrm{~g}, \mathrm{t}=2 \mathrm{hrs}$ and $\mathrm{C}=120 \mathrm{ppm}$.

\subsubsection{The effects of factor on removal efficiency and adsorption capacity}

The removal efficiency and adsorption capacity of mordant black-11 dye is studied in terms of: Effect of concentration, $\mathrm{pH}$, and contact time.

\subsection{3. pH on removal efficiency (R1) and adsorption capacity (R2)}

The effect of solution $\mathrm{pH}$ on the removal efficiency of dye and adsorption process was studied by varying the initial $\mathrm{pH}$ of the solution from 3 to 12 . The optimum $\mathrm{pH}$ was achieved at $\mathrm{pH} 9$. 


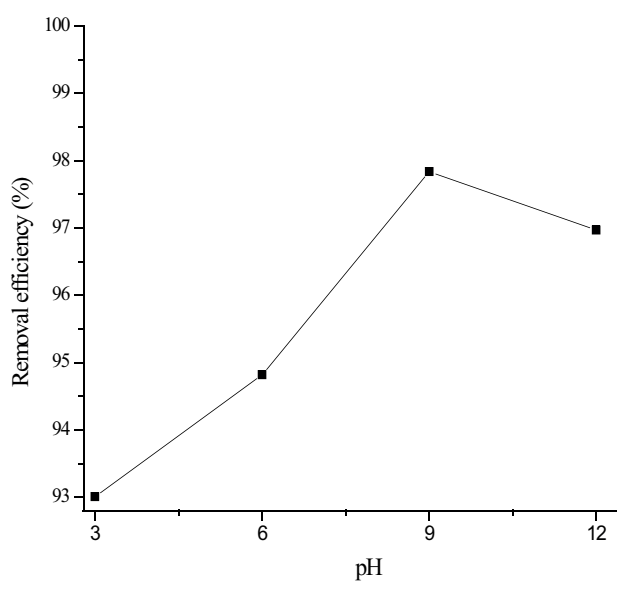

a) dye removal efficiency

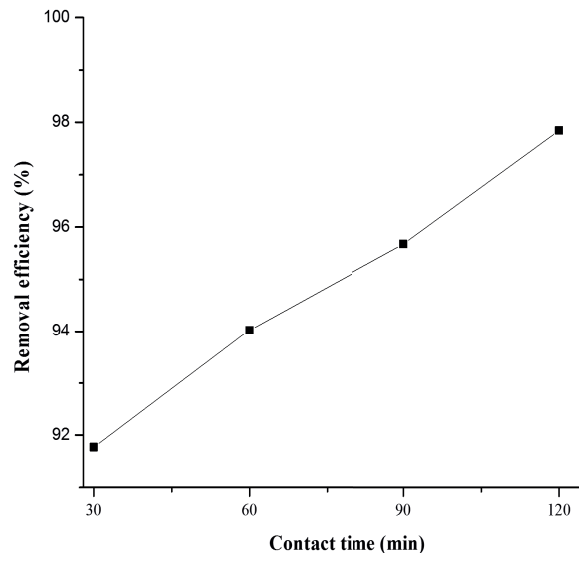

a) dye removal efficiency

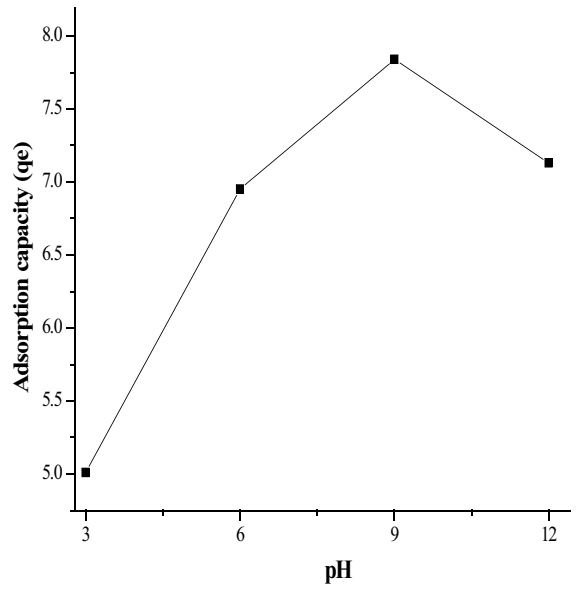

b) adsorption capacity

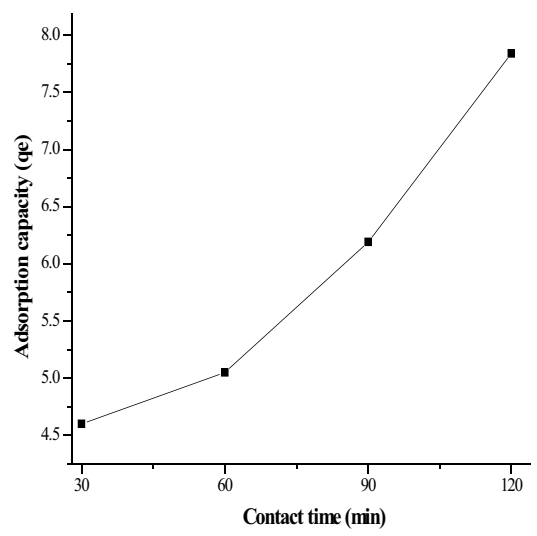

b) adsorption capacity

Figure 19: Effects of contact time on dye removal efficiency \& adsorption capacity: dose $=2 \mathrm{~g}, \mathrm{pH}=9$ and $\mathrm{C}=$ $120 \mathrm{ppm}$.

\subsubsection{Contact time on removal efficiency (R1) and adsorption capacity ( $R 2$ )}

Contact time on removal efficiency and adsorption capacity were examined. In both cases as contact time increases removal and adsorption would increased. As usual trend the reason is the chance of active cites would get more contact with dyes as time goes longer.

\subsubsection{Normalized plot \& predicted/Actual on removal and adsorption}

\subsection{Optimization of red Azo dye}

Three factors (concentration, $\mathrm{pH} \&$ contact time) and four label for each operating condition. 

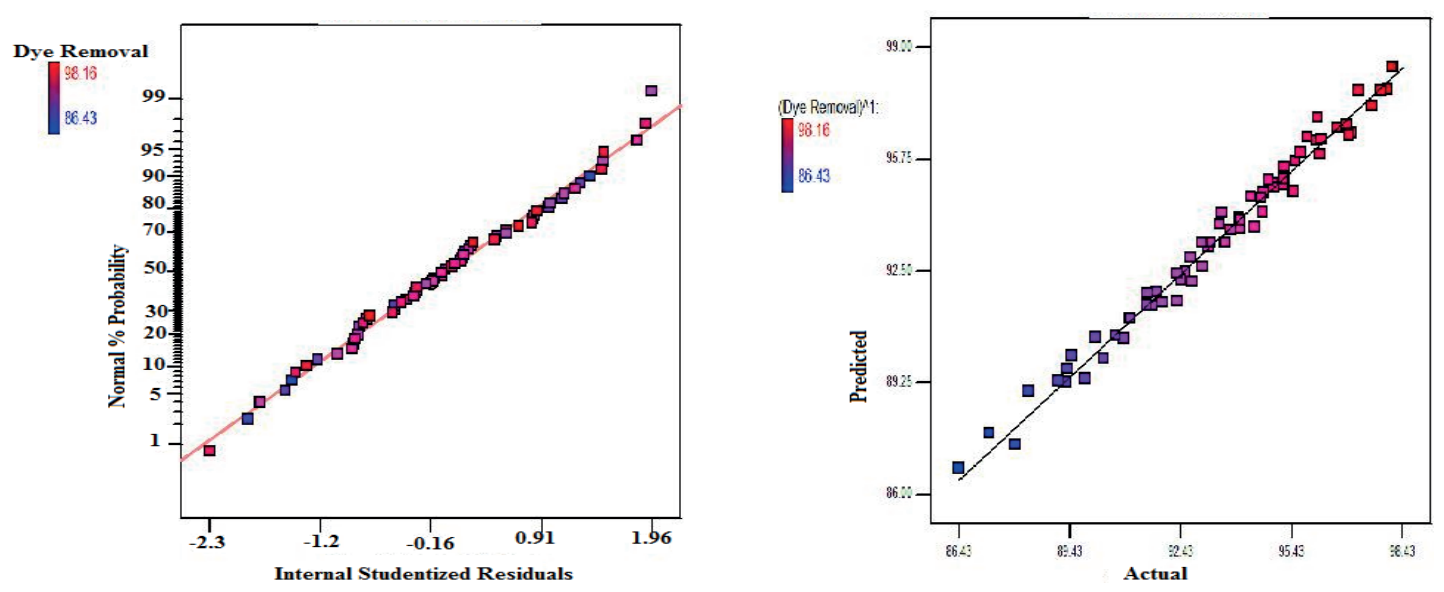

Figure 20: Normalized \& predicted vs Actual plots.

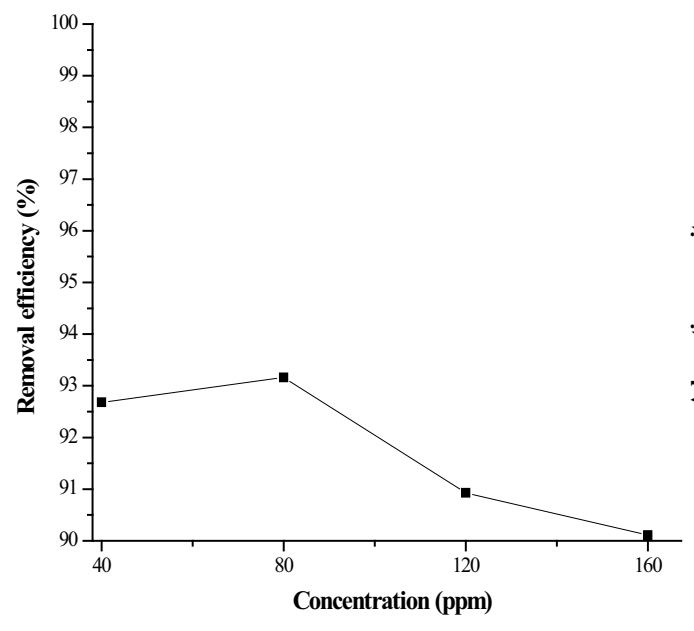

a) removal efficiency

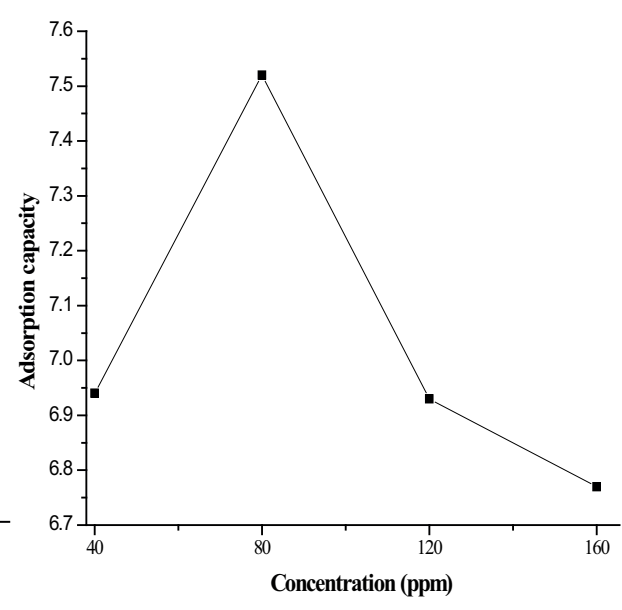

b) adsorption capacity

Figure 21: Effects of concentration on removal efficiency \& adsorption capacity: dose $=2 \mathrm{~g}, \mathrm{t}=2 \mathrm{hrs}$ and $\mathrm{pH}=6$.

\subsubsection{Optimization of process parameter results}

In this study red color azo dye were analyzed at different operating condition for 64 run by varying the factors. Therefore, the optimum operating condition were obtained as follows, the concentration (40-160), in $40 \mathrm{ppm}$ interval for concentration, $\mathrm{pH}(3-12)$ in 3 interval and contact time (30-120 minutes) of which 30 minutes interval. Finally, maximum removal efficiency and adsorption capacity the optimum points were 80 ppm, pH 6 and contact time 120 minutes obtained respectively. 


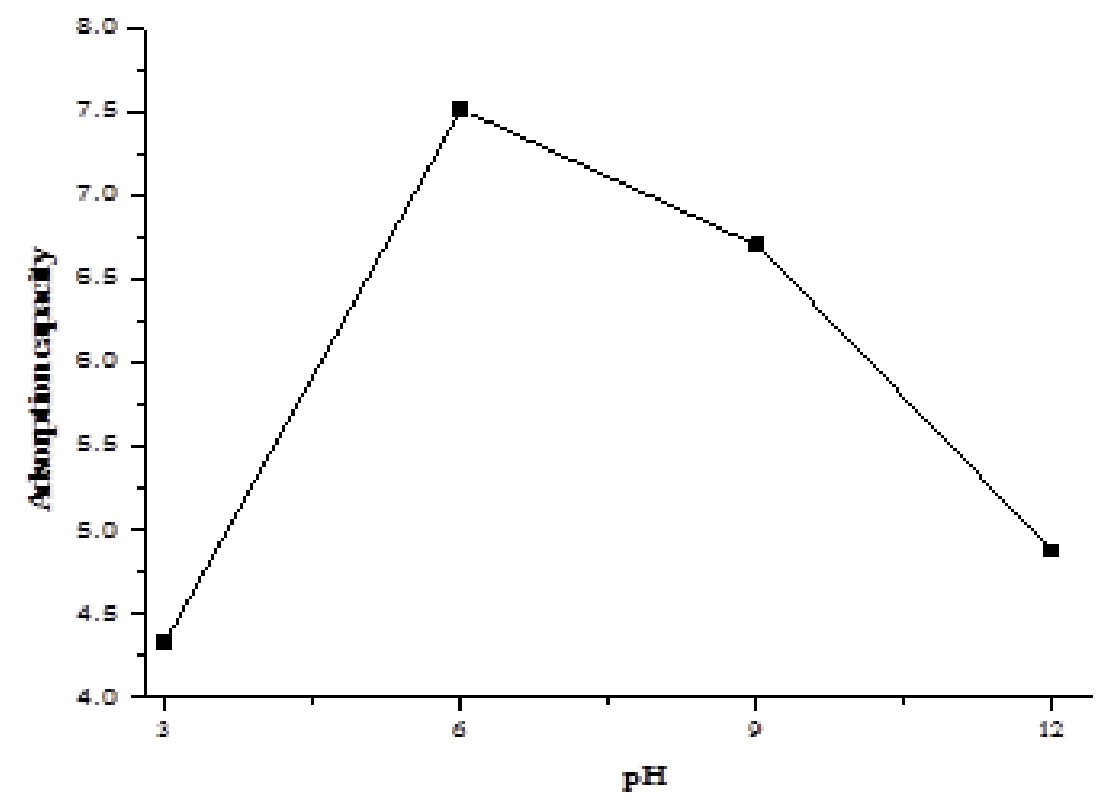

Figure 22: Effects of $\mathrm{pH}$ on adsorption capacity: dose $=2 \mathrm{~g}, \mathrm{t}=2 \mathrm{hrs}$ and $\mathrm{C}=80 \mathrm{ppm}$.

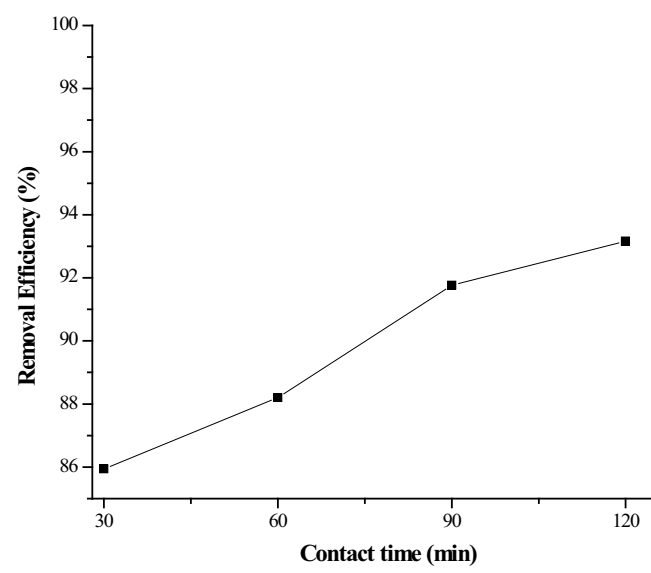

a) Removal efficiency

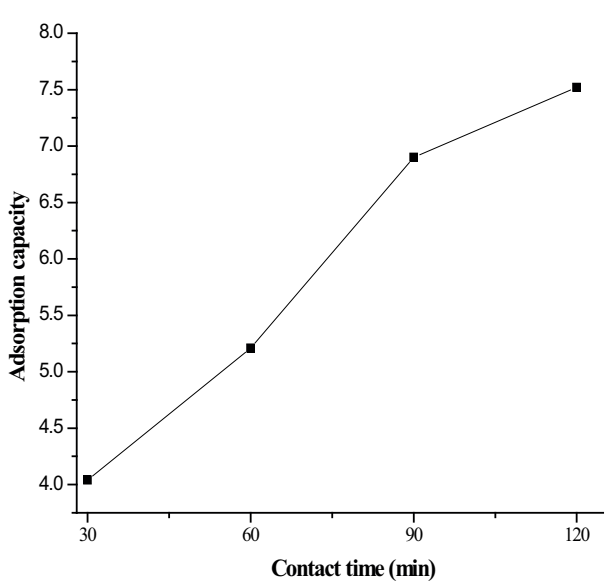

b) Adsorption capacity

Figure 23: Effects of contact time on removal efficiency \& adsorption capacity: dose $=2 \mathrm{~g}, \mathrm{pH}=6$ and $\mathrm{C}=80 \mathrm{ppm}$.

\subsubsection{The effects of factor on dye removal efficiency and adsorption capacity}

The removal efficiency and adsorption capacity of red color azo dye is studied in terms of: Effect of concentration, Effect of $\mathrm{pH}$ and Effect of contact time.

\subsection{3. pH on dye decolorizing efficiency (R1) and adsorption capacity ( $\mathbf{R 2}$ )}

As per the optimization the $\mathrm{pH} 6$ of the dye solution would yield maximum adsorption capacity and red azo dye more adsorbed on the surface of activated carbon. 


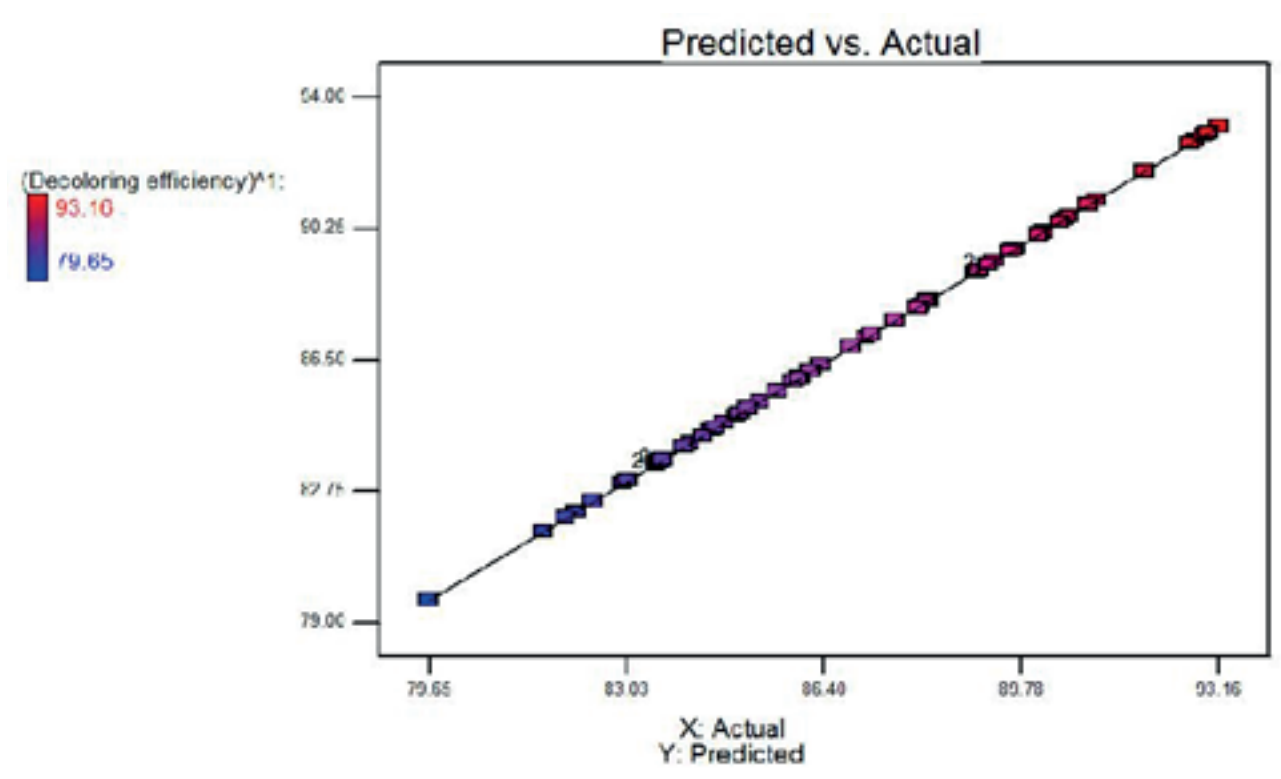

Figure 24: Predicted vs Actual plots on decolorizing efficiency.

\subsection{Adsorption Isotherms}

In this study chromium and both mordant black-11 and red color azo dye were analyzed by the assumption of Langmuir and Freundlich models, in order to identify which model would well fitted as one of selection criteria. The Langmuir model assumes that the uptake of dye occurs on a homogenous surface by monolayer adsorption without any interaction between adsorbed ions. However, the Freundlich model assumes that the uptake of dyes occurs on a heterogeneous surface by monolayer adsorption.

\subsubsection{Model for Langmuir Isotherm}

The Langmuir isotherm can be mathematically expressed as:

$$
\begin{gathered}
\frac{C}{q}-\frac{1}{K_{A} q_{m}}+\frac{1}{q_{m}} C \\
\text { slope }-\frac{1}{q_{m}} \quad \text { intercept }=\frac{1}{K_{A} q_{m}}
\end{gathered}
$$

\subsubsection{Freundlich and Langmuir isotherm for chromium}

Freundlich isotherm is more suitable isotherm model than Langmuir isotherm model since tcorrelation factor (R2) 0.9365 .

\subsubsection{Mordant black-11 and Azo dyes}

Both mordant black-11 and azo dyes were Langmuir and Freudlich isotherm respectively represented graphically as follow. 


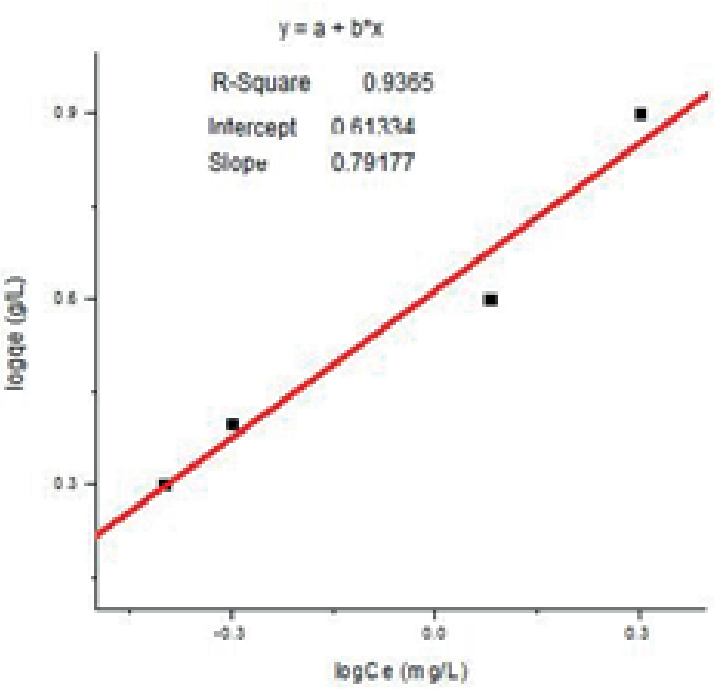

Figure 25: Freundlich isotherm.

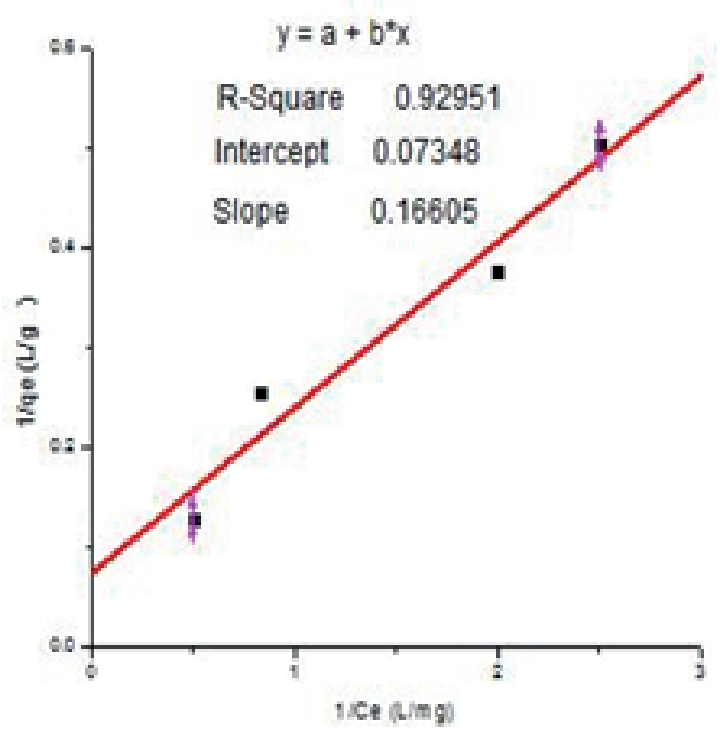

Figure 26: Langmuir isotherm.

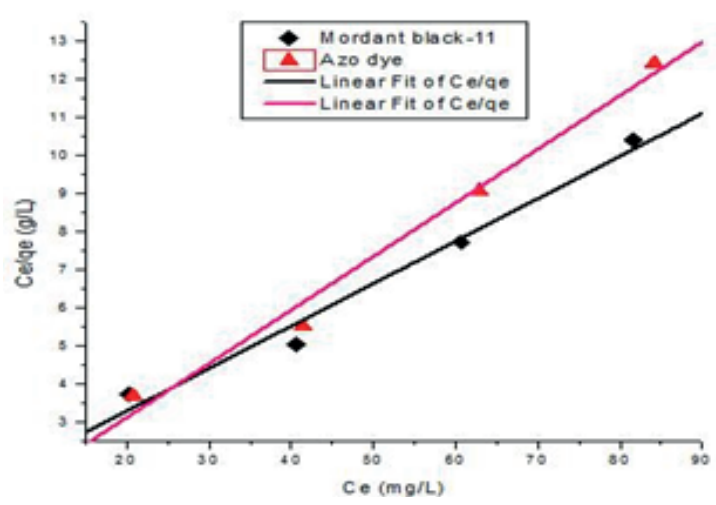

Figure 27: Langmuir isother for Mordant black-11 and Azo dyes. 


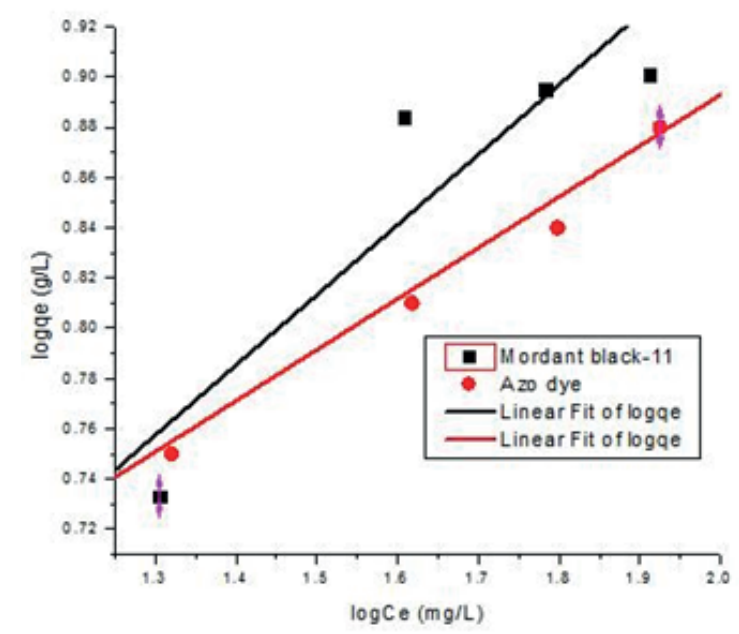

Figure 28: Freundlich isotherm for Mordant black-11 and Azo dyes.

Table 7: Isotherm models \& correlation coefficients for adsorption of mordant black-11 \& azodye on FTWAC.

\begin{tabular}{l|c|c|c|c|c|}
\hline \multirow{2}{*}{$\begin{array}{l}\text { Type of models } \\
\text { Langmuir }\end{array}$} & Types of dyes & Adsorbent & Slop & Intercept & R2 \\
\hline & Mordant black-11 & Flashed & 0.1115 & 1.0677 & 0.968 \\
\hline \multirow{3}{*}{ Freundlich } & Azo dye & & 0.1408 & 0.3115 & 0.977 \\
& Mordant black-11 & & 0.2813 & 0.3886 & 0.765 \\
\cline { 2 - 6 } & Azo dye & & 0.2076 & 0.4743 & 0.984 \\
\hline
\end{tabular}

\subsubsection{Model for Freundlich Isotherm}

For the special case of heterogeneous surface energies (particularly good for mixed wastes) in which the energy term, "KF", varies as a function of surface coverage we use the Freundlich model. The Freundlich equation can be mathematically represented by:

$$
\begin{gathered}
\log q=\log K_{F}+\frac{1}{n} \log C \\
\text { intercept }=\log K_{F} \quad \text { slope }=\frac{1}{n}
\end{gathered}
$$

Here the correlation coefficients of azo dye in both cases of Langmuir and Freundlich 97.7\% and $98.4 \%$ respectively. However, Freundlich model for azo dye comparatively it is well fitted.

\section{Conclusion}

The ultimate objectives of this research was the removal of chromium and azo metal-complex dyes using activated carbon synthesized from tannery wastes, as a primary treatment of toxic wastes. Moreover, the activated carbon synthesized from fleshed parts of the tannery solid waste is competitive with any other technique and commercial activated carbon. Based on the results 
of this investigation, it can be concluded that:

1. The bulk density, moisture content, volatile matter and ash content of the fleshed tannery waste activated carbon shows good result which is $0.61 \mathrm{~g} / \mathrm{cm}^{3}, 4,41$ and $40 \%$ respectively. According to this study the removal efficiency and adsorption capacity of FTWAC were checked its removal of test and odor for tannery effluents by phenol number method removed over $88 \%$ of its test and odor.

2. Due to acid activation method, the $\mathrm{pH}$ of prepared activated carbon would be in acidic range of $\mathrm{pH} 5.3$ and in addition the activated carbon was tasted using FTIR which showed that the active site has acidic functional group.

3. The FTWAC surface area that was characterized in BET instrument is $535.02 \mathrm{~m}^{2}$. However, the promising surface area was obtained when we compared with other source of activated carbon.

4. Finally, the optimum condition of removal and adsorption capacity (adsorbent dose, $\mathrm{pH}$ and contact time for $\mathrm{Cr}(\mathrm{VI})$ ) and (initial concentration, $\mathrm{pH}$ and contact time for both mordant black-11 and red azo dyes) were also estimated. In this study, for $\mathrm{Cr}(\mathrm{VI})$ the maximum removal efficiency and adsorption capacity over $99 \%$ and $7.8 \mathrm{mg} / \mathrm{g}$ results were obtained at lower $\mathrm{pH}$ of 3, 2 gram dose and 120 minutes of contact time. In addition mordant black11 and red azo dyes were shows maximum removal efficiency obtained at $\mathrm{pH} 9$ over 97\% for MB-11 and pH 6 over 93\% for red AD with optimum initial concentration $120 \mathrm{ppm}$ for MB-11 and $80 \mathrm{ppm}$ for red AD from the rang of 40-160 ppm selected. Furthermore contact time for $\mathrm{Cr}(\mathrm{VI})$ and both dyes 120 minutes were obtained the maximum as per the optimization. Freundlich isotherm model was well fitted.

5. It is true that Bahir Dar leather factory can support economic development of the nation by generating foreign currency and employment opportunity for the citizens, but undeniable cause for environmental pollution and workers, due to the absence of proper waste treatment and disposal system and inadequate safety equipments, the tannery is causing adverse impacts on the workers and the community. Therefore, Bahir Dar leather tannery can generate the highest amount of tannery wastes; its possible to convert solid wastes into activated carbon can be used as a best option for treating such toxic compounds.

\section{Competing Interests}

The authors declare that they have no competing interests.

\section{References}

[1] L. A.-A. R. Al-Rubaie and R. J. Mhessn, Synthesis and characterization of Azo dye para red and new derivatives, E-Journal of Chemistry, 9, no. 1, 465-470, (2012).

[2] A. W. Adhena, H. Nigus, and D. B. Hayelom, Removal of hexavalent chromium from tannery wastewater using activated carbon primed from sugarcane bagasse: Adsorption/Desorption studies, 2, 128-135, 2(6, 2014.

[3] A. E. Ahmed Said, M. A. A. Aly, M. M. Abd El-Wahab, S. A. El-Fadeel Soliman, A. El-Hafez, V. A, and M. N. Goda, An Efficient Biosorption of Direct Dyes from Industrial Wastewaters Using Pretreated Sugarcane Bagasse, Energy and Environmental Engineering, 1, no. 1, 10-16, (2013). 
[4] R. C. Bansal and M. Goyal, Activated Carbon Adsorption, 238, CRC Press, Boca Raton, FL, 2005.

[5] R. R. Bansode, J. N. Losso, W. E. Marshall, R. M. Rao, and R. J. Portier, Adsorption of volatile organic compounds by pecan shell- and almond shell-based granular activated carbons, Bioresource Technology, 90 , no. 2, 175-184, (2003).

[6] A. A. Belay, Impacts of chromium from tannery effluent and evaluation of alternative treatment options, Journal of Environmental Protection, 53-58, (2010).

[7] M. H. Cheng, J. W. Patterson, and R. A. Minear, Heavy metals uptake by activated sludge, Journal of the Water Pollution Control Federation, 47, no. 2, 362-376, (1975).

[8] W. Chu, Dye removal from textile dye wastewater using recycled alum sludge, Water Research, 35, no. 13, 3147-3152, (2001).

[9] B. V. Devi, A. A. Jahagirdar, and M. N. Zulfiqar Ahmed, Adsorption of Chromium on Activated Carbon Prepared from Coconut Shell, 2, 364-370

[10] C. Elinge, A. M, I. U, U. J, A. A, and N. , Agricultural wastes for treatment of waste water, Advances in Applied Science Research, 2, no. 4, 279-283, (2011).

[11] C. Fernandes, V. S. Lalitha, and K. V. K. Rao, Enhancing effect of malachite green on the development of hepatic pre-neoplastic lesions induced by N-nitrosodiethylamine in rats, Carcinogenesis, 12, no. 5, 839-845, (1991).

[12] K. S. Geetha and S. L. Belagali, Removal of Heavy Metals and Dyes Using Low Cost Adsorbents from Aqueous Medium- A Review. IOSR Journal of Environmental Science, Toxicology and Food Technology, 56-68, (2013).

[13] C. Hauber and J. Buljan, Formation, prevention and determination of $\mathrm{Cr}(\mathrm{VI})$ in leather, A review, Journal of the American Leather Chemists Association, 92, 119-130, (2000).

[14] A. L. Henderson, T. C. Schmitt, T. M. Heinze, and C. E. Cerniglia, Reduction of malachite green to leucomalachite green by intestinal bacteria, Applied and Environmental Microbiology, 63, no. 10, 4099-4101, (1997).

[15] S. Henderson, P. Sawangchit, and Vuthiphandchai. , Removal of Malachite green employing physical and biological processes, Journal of Science, 30, 351-352, (2004).

[16] C. P. Huang and M. H. Wu, Removal of chromium(VI) from dilute aqueous solution by activated carbon, $J$. Water. Pollution and Control. Federation, 47, 389-393, (1975).

[17] B. Linhares, C. T. Weber, E. L. Foletto, D. S. Paz, M. A. Mazutti, and G. C. Collazzo, Activated carbon prepared from yerba mate used as a novel adsorbent for removal of tannery dye from aqueous solution, Environmental Technology (United Kingdom), 34, no. 16, 2401-2406, (2013).

[18] S. F. Montanher, E. A. Oliveira, and M. C. Rollemberg, Removal of metal ions from aqueous solutions by sorption onto rice bran, Journal of Hazardous Materials, 117, no. 2-3, 207-211, (2005).

[19] H. Ozgunay, S. Colak, M. M. Mutlu, and F. Akyuz, Characterization of leather industry wastes, Polish Journal of Environmental Studies, 16, no. 6, 867-873, (2007).

[20] S. L. Pandharipande, Y. D. Urunkar, and A. Singh, Reduction of COD and chromium, and decolourisation of tannery wastewater by activated carbons from agro-wastes, Journal of Scientific and Industrial Research, 71, no. 7, 501-503, (2012).

[21] S. Rengaraj, K.-H. Yeon, and S.-H. Moon, Removal of chromium from water and wastewater by ion exchange resins, Journal of Hazardous Materials, 87, no. 1-3, 273-287, (2001).

[22] T. Robinson, G. McMullan, R. Marchant, and P. Nigam, Remediation of dyes in textile effluent: A critical review on current treatment technologies with a proposed alternative, Bioresource Technology, 77, no. 3, 247-255, (2001).

[23] F. Rodríguez-Reinoso, Introduction to Carbon Technologies, Publicaciones de la Universidad de Alicante, 145, 381-390, (1997).

[24] V. Sivakumar, M. Asaithambi, and P. Sivakumar, Physico-chemical and adsorption studies of activated carbon from Agricultural wastes, Advances in Applied Science Research, 3, no. 1, 219-226, (2012).

[25] D. R. Waring and G. Hallas, The chemistry and application of dyes (1990).

[26] J. Yener, T. Kopac, G. Dogu, and T. Dogu, Adsorption of Basic Yellow 28 from aqueous solutions with clinoptilolite and amberlite, Journal of Colloid and Interface Science, 294, no. 2, 255-264, (2006).

[27] Y. Shinogi and Y. Kanri, Pyrolysis of plant, animal and human waste: Physical and chemical characterization of the pyrolytic products, Bioresource Technology, 90, no. 3, 241-247, (2003). 